Review

\title{
Environmental Enrichment for Rats and Mice Housed in Laboratories: A Metareview
}

\author{
Anna S. Ratuski *(D) and Daniel M. Weary *(D) \\ Animal Welfare Program, Faculty of Land and Food Systems, University of British Columbia, \\ Vancouver, BC V6T 1Z4, Canada \\ * Correspondence: annaratuski@gmail.com (A.S.R.); dan.weary@ubc.ca (D.M.W.)
}

Citation: Ratuski, A.S.; Weary, D.M. Environmental Enrichment for Rats and Mice Housed in Laboratories: A Metareview. Animals 2022, 12, 414. https://doi.org/10.3390/ ani12040414

Academic Editors: Wendy Y. Brown, Peta Taylor and Megan Verdon

Received: 31 December 2021

Accepted: 30 January 2022

Published: 9 February 2022

Publisher's Note: MDPI stays neutral with regard to jurisdictional claims in published maps and institutional affiliations.

Copyright: (C) 2022 by the authors. Licensee MDPI, Basel, Switzerland. This article is an open access article distributed under the terms and conditions of the Creative Commons Attribution (CC BY) license (https:/ / creativecommons.org/licenses/by/ $4.0 /)$.
Simple Summary: Environmental enrichment has been widely studied with laboratory rodents, but there is no consensus regarding what counts as enrichment or what it should achieve. Inconsistent use of the term "enrichment" creates challenges in drawing conclusions about the quality of an environment. We conducted a metareview to better understand the definitions and goals of enrichment, perceived risks or requirements of enrichment, and what forms of enrichment have previously been endorsed for use with rodents housed in laboratories. This may help researchers and animal care staff to better define their chosen approach and intended outcomes when providing environmental enrichment.

Abstract: Environmental enrichment has been widely studied in rodents, but there is no consensus on what enrichment should look like or what it should achieve. Inconsistent use of the term "enrichment" creates challenges in drawing conclusions about the quality of an environment, which may slow housing improvements for laboratory animals. Many review articles have addressed environmental enrichment for laboratory rats and mice (Rattus norvegicus and Mus musculus). We conducted a metareview of 29 review articles to assess how enrichment has been defined and what are commonly described as its goals or requirements. Recommendations from each article were summarised to illustrate the conditions generally considered suitable for laboratory rodents. While there is no consensus on alternative terminology, many articles acknowledged that the blanket use of the terms "enriched" and "enrichment" should be avoided. Environmental enrichment was most often conceptualised as a method to increase natural behaviour and improve animal welfare. Authors also commonly outlined perceived risks and requirements of environmental enrichment. We discuss these perceptions, make suggestions for future research, and advocate for the adoption of more specific and value-neutral terminology.

Keywords: refinement; laboratory animals; rodent; animal welfare; environmental complexity

\section{Introduction}

There are many incongruencies between the natural adaptations of mice (Mus musculus) and rats (Rattus norvegicus) and the laboratory conditions in which they are typically housed (for mice, see [1,2]; for rats, see [3,4]). There has been some speculation on whether laboratory rodents have the same needs as their wild counterparts, with some arguing that laboratory rodents are adapted to life in cages (e.g., [5-7]). While it is reasonable to assume some differences in behaviour after generations of captive breeding, there is little evidence that domestication results in a reduced behavioural repertoire. Rather, domestication and captive environments tend to alter the frequency of behavioural expressions and the strength or nature of stimuli required to elicit them [8]. When given access to a burrowing substrate, for example, mice and rats in laboratories readily perform this behaviour [9-12]. Rather than accommodating a full repertoire of behaviours, housing for rodents used in research has largely focused upon standardisation and convenience for humans [13]. 
While some improvements to housing have been made (e.g., the shift from suspended wire cages to solid-bottom cages with bedding [14]), there is mounting evidence that current practices negatively impact welfare. Laboratory cages restrict the expression of behaviours such as burrowing, foraging, exploration, climbing, and more complex social interactions. Captive environments that prevent natural behaviours can cause frustration, stress, depression, and behaviours indicative of poor welfare [15,16]. For rodents, conventional laboratory cages (which we define here as polycarbonate cages with bedding and possibly nesting material and/or a shelter, with food pellets provided in a metal food hopper) can lead to the development of stereotypic behaviours [17-19], weakened immune responses [20,21], increased acute hormonal responses to stressors [22], and behaviours indicative of anxiety $[23,24]$ and pain [25]. Individually ventilated cages are also increasingly used, offering increased biosecurity but impairing animal thermoregulation [26].

Early versions of guidelines for laboratory animal husbandry have typically excluded environmental enrichment for rodents (e.g., [27]). This is changing with time, with some guidelines providing minimally acceptable enrichment components [28,29] and others encouraging enrichment more generally [14]. In recent years, there has been a push to improve the lives of animals used in research (e.g., [30,31]). To use animals ethically in research, some authors have suggested that we must provide them with environments that promote a "good life" [32] or maximise the potential for an animal's needs to be fulfilled [33]. Beyond ethical arguments, there are pragmatic concerns relating to the effect of poor animal welfare on the quality of scientific results $[34,35]$. As such, the use of environmental enrichment has been promoted for animals housed in laboratories.

\section{What Is Enrichment for Rodents?}

Definitions and applications of environmental enrichment tend to vary widely between studies. Indeed, the environmental enrichment literature has been criticised for inconsistent usage of terms and lack of precise definitions (e.g., [36,37]). Some studies (all from roughly the last decade) refer to the addition of nesting material (to an otherwise barren cage) as enriched (e.g., $[23,38,39])$, although in other studies a cage with nesting material is sometimes used as a condition representing no enrichment (e.g., [40,41]). Other studies refer to cages containing nesting material in addition to other components as their conventional or non-enriched condition (e.g., [42,43]), and many studies do not describe their conventional housing conditions at all [21], making direct comparisons between studies difficult. Because the term is variously applied, an otherwise barren cage altered in any way might be labelled as "enrichment." As one example of such practices, a shoebox cage for mice modified to have one indented corner has recently been marketed as enriched [44]. Such usage of the term dilutes its meaning, promotes continued provision of sub-optimal environments, and creates challenges in drawing conclusions about the effects of enrichment.

Environmental enrichment has been widely studied with rodents. Approximately $70 \%$ of enrichment studies from 1985 to 2004 focused on laboratory animals, especially rodents. Publications on this topic appeared in the literature with increasing frequency from 1999 onward, related to growing interest from neuroscientists [45], and this trend has continued to date [46]. A PubMed search for "environmental enrichment" and "rats" or "mice" identified 662 publications from 2020 alone. This may be related to increasing use of the ARRIVE guidelines [47], which recommend disclosing information on housing and husbandry in publications (however, a recent revision has moved environmental enrichment into the category of recommended rather than essential reporting [48]). Despite increasing information surrounding enrichment use with rodents, varied definitions and applications of enrichment contribute to difficulty in drawing conclusions. In neuroscience research, enrichment is often conceptualised and applied as a research paradigm assessing the effects of environmental complexity or novelty on disease progression, brain development, and brain function. Outside of neuroscience research, enrichment is often conceptualised as an application intended to enhance animal welfare, with some scholars labelling all environ- 
mental components as "enrichment", and others reserving the term only for the provision of components that surpass minimum environmental requirements. These different approaches to the conceptualisation of enrichment have likely contributed to variation in its perceived effects.

With growing interest in the topic, it is important to clarify how enrichment is conceptualised and applied. Many review articles have summarised and discussed environmental enrichment, providing commentary on both theoretical and practical aspects. The present article provides a metareview of these review articles, summarising how enrichment has been defined, what are described as its goals, and what are perceived as risks or requirements of enrichment. Recommendations from each article are also summarised to illustrate the range of conditions considered appropriate for laboratory rodents. We conclude with a general discussion of how to move forward with the application and study of environmental enrichment for rats and mice.

\section{Methods}

We emulated the approach of a systematic review such that our search strategy and inclusion criteria were comprehensive and could be replicated. However, our aim was to clarify key concepts and definitions from the literature rather than to perform a metaanalysis of primary research findings; therefore, our methodology aligns with that of a scoping review rather than a systematic review [49]. Given that we focused only on review articles in our search, we have used the term "metareview".

\subsection{Search Strategy}

A search was performed on three academic databases (Web of Science Core Collection, PubMed, and CAB Direct) on 1 March 2021. The following search terms were used on Web of Science: ((rodent OR rat OR mice) AND ("environmental enrichment" OR enrich* OR caging OR cage* OR housing OR environment)). We also specified document type (review articles). This search yielded 65 publications. The same search terms were used on $C A B$ Direct; results were further refined by available topics: reviews, laboratory animals, animal research, animal husbandry, animal models, behaviour, animal behaviour, animal welfare, or animal housing; this search yielded 185 publications. On PubMed, the following search terms were used: ((rat) OR (mice) OR (rodent)) AND (animal welfare) AND (("environmental enrichment") OR (enrich* adj1 (environment OR cage* OR caging OR housing))); this yielded 98 publications. All references were loaded into Covidence systematic review software and duplicates were removed. Titles and abstracts were screened using our inclusion criteria described in the following section. Full text screening and data extraction were performed independently by two reviewers. All articles that met the inclusion criteria had their reference lists screened for potential additional articles.

\subsection{Inclusion Criteria}

No publication date limits were imposed. Primary research articles and books were excluded. Only articles written in English were included. Articles had to be focused on "environmental enrichment" (or any described alternate term such as environmental complexity) for laboratory rats or mice; articles discussing a variety of species used in laboratories were acceptable if there was commentary dedicated to rats or mice. We did not seek out reviews on specific forms of environmental enrichment (e.g., social housing). Included articles had to discuss the use of environmental enrichment as a method to refine housing or husbandry practices; reviews on use of environmental enrichment purely as an experimental paradigm or therapeutic intervention (i.e., for disease models) were excluded. Articles did not need to be comprehensive or systematic reviews. As such, many articles addressed specific aspects of enrichment, such as its "unintended outcomes" [50], provision of foraging opportunities [51,52], and effects on variability of research outcomes [46,53,54]. Reported summaries of recommended enrichment strategies should be interpreted with 
this in mind, as failure to discuss a specific type of enrichment within one context does not mean that it would be excluded in another.

\section{Results and Discussion}

In total, 29 articles were included (Figure 1). One article was excluded at the fulltext screening stage because it was focused on the use of enrichment as an experimental paradigm only and did not include discussion of general husbandry practices. Articles were published over a 30-year span (from 1991 to 2021). Data are summarised in Table 1.

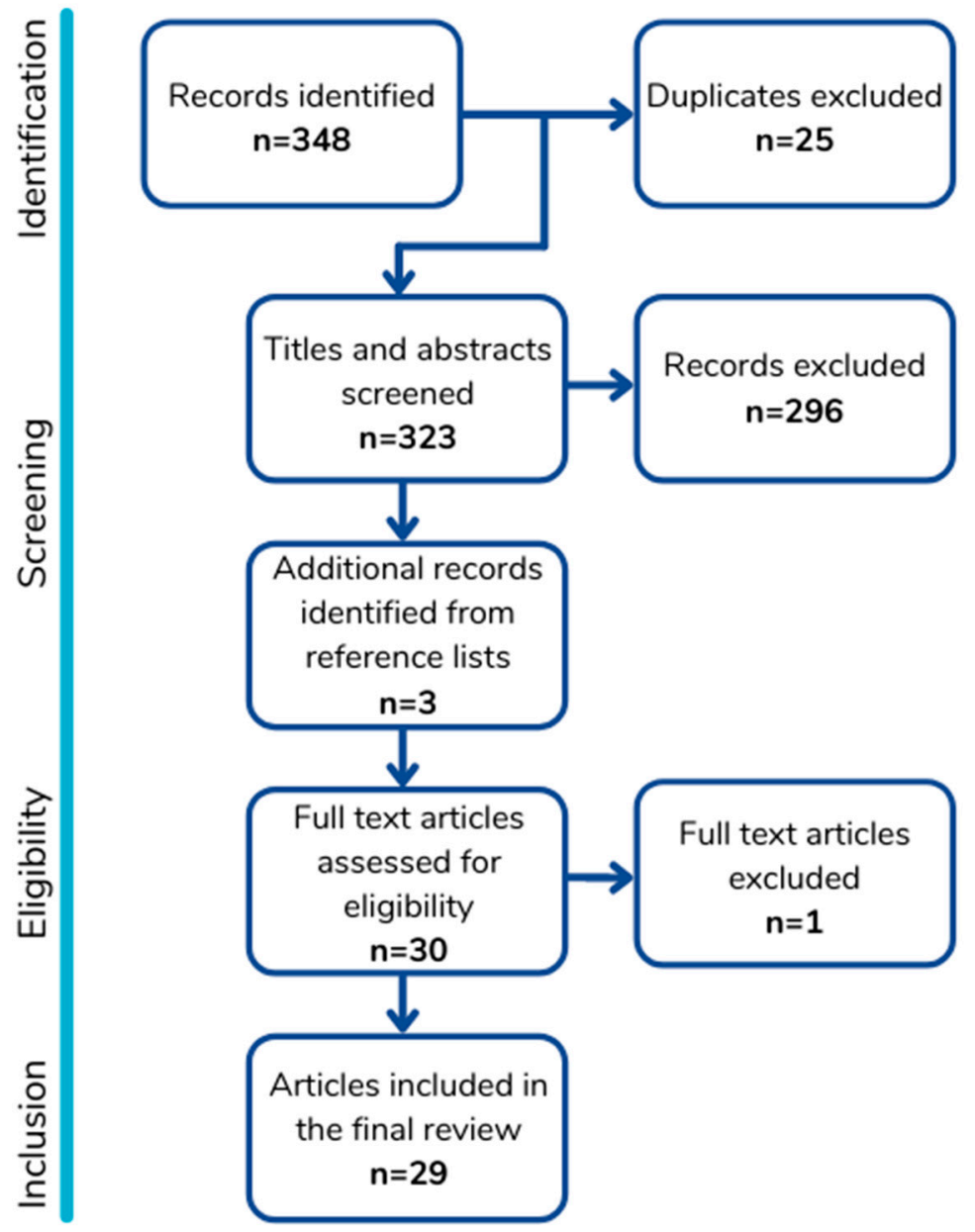

Figure 1. Diagram showing our process of identifying and screening articles for eligibility and inclusion, resulting in the 29 articles included in this metareview.

In the sections that follow, we outline the main findings from Table 1, critically discussing the prevalent themes. Definitions and goals of enrichment are discussed together within the same section. We then discuss enrichment components recommended in these reviews. Lastly, the risks or requirements of enrichment are discussed. We end with a general discussion concerning enrichment for rodents, as well as conclusions and recommendations for future work. 
Table 1. Summary of definitions, goals, requirements or risks of environmental enrichment (EE), and recommended forms of EE, as described in review articles on the topic. "Additional requirements or risks of EE" consisted of any aspect that was indicated by authors, using words like "must" or "should", as a necessity for successful implementation of enrichment, or otherwise identified as a barrier or potential risk of enrichment. "Recommended EE" lists components specified by authors as something that should (or should not) be provided to mice or rats; general discussions about forms of enrichment without a specific conclusion or recommendation were not included here. Note that definitions of EE often quoted or referenced other publications; these citations are excluded from the table.

\begin{tabular}{|c|c|c|c|c|c|}
\hline $\begin{array}{l}\text { Author and } \\
\text { Year }\end{array}$ & Species & Definition of EE & Specific Goals of EE & Additional Requirements or Risks of EE & Recommended EE \\
\hline \multirow[b]{2}{*}{$\begin{array}{l}\text { Scharmann, } \\
1991 \text { [13] }\end{array}$} & \multirow[b]{2}{*}{ Both } & \multirow[b]{2}{*}{$\begin{array}{l}\text { - } \quad \text { Housing animals "in a } \\
\text { manner conducive to their } \\
\text { 'psychological well-being'" }\end{array}$} & \multirow[b]{2}{*}{$\begin{array}{l}\text { - } \quad \text { Enable animals to express } \\
\text { species-specific behaviours } \\
\text { - Create circumstances "that } \\
\text { will enhance the animals' } \\
\text { welfare, even to the point of... } \\
\text { giving them the benefit of the } \\
\text { doubt, or of being generous } \\
\text { toward them" }\end{array}$} & \multirow[b]{2}{*}{$\begin{array}{ll}\text { - } & \text { EE should not result in extensive } \\
\text { additional work for staff } \\
\text { - } & \text { EE must meet hygienic requirements } \\
\text { - } & \text { EE should not impede inspection of } \\
\text { the animals } \\
\text { - } \quad \text { Resistance from experimenters }\end{array}$} & For rats: \\
\hline & & & & & $\begin{array}{l}\text { Higher cages to allow for standing } \\
\text { and sufficient space for play } \\
\text { - } \quad \begin{array}{l}\text { Opportunities for activity such as } \\
\text { gnawing or tugging paper material } \\
\text { through the cage lid }\end{array} \\
\text { For mice: } \\
\text { - } \quad \text { Use of vertical cage space to } \\
\text { provide opportunities for mice } \\
\text { to climb } \\
\text { - } \quad \text { Nesting material } \\
\text { - } \quad \text { Foraging opportunities }\end{array}$ \\
\hline \multirow{3}{*}{$\begin{array}{l}\text { Dean, } \\
1999 \text { [55] }\end{array}$} & \multirow{3}{*}{ Both } & \multirow{3}{*}{$\begin{array}{l}\text { - } \text { “... any measure which } \\
\text { promotes expression of } \\
\text { natural, species-specific } \\
\text { behaviours and a decrease } \\
\text { in, if not disappearance of, } \\
\text { abnormal behaviours" }\end{array}$} & \multirow{3}{*}{$\begin{array}{ll}\text { - } & \text { Improve animal well-being } \\
\text { - } & \text { Make animal lives more } \\
\text { comfortable and interesting } \\
\text { - Encourage "normal" } \\
\text { behaviours, decrease } \\
\text { abnormal behaviours }\end{array}$} & \multirow{3}{*}{$\begin{array}{l}\text { - The notion of "historical data" and the } \\
\text { desire for results to be comparable to } \\
\text { those of previous studies } \\
\text { - The impact of confounding variables } \\
\text { introduced by EE must be minimised } \\
\text { - } \quad \text { Resistance from researchers } \\
\text { - } \quad \text { Financial costs } \\
\text { - } \quad \text { Limited staff time }\end{array}$} & For rats: \\
\hline & & & & & $\begin{array}{l}\text { - Inclusion of solid inserts on grid } \\
\text { floors, or the inclusion of a shelf } \\
\text { within the cage } \\
\text { - } \quad \text { Hard pelleted diet } \\
\text { - } \quad \text { Background music to dull impacts } \\
\text { of sudden noise } \\
\text { For mice: } \\
\text { - } \quad \text { Plastic bottles or shelters } \\
\text { - } \quad \text { Pelleted diet } \\
\text { For both. }\end{array}$ \\
\hline & & & & & $\begin{array}{l}\text { Nest boxes with paper } \\
\text { nesting material } \\
\text { - Social housing }\end{array}$ \\
\hline
\end{tabular}


Table 1. Cont.

\begin{tabular}{|c|c|c|c|c|c|}
\hline $\begin{array}{l}\text { Author and } \\
\text { Year }\end{array}$ & Species & Definition of EE & Specific Goals of EE & Additional Requirements or Risks of EE & Recommended EE \\
\hline $\begin{array}{l}\text { Galef, } \\
1999 \text { [56] }\end{array}$ & Both & $\begin{array}{l}\text { - } " \ldots \text { changes in the } \\
\text { physical or social } \\
\text { environment [to] } \\
\text { increase rodents' } \\
\text { psychological welfare" }\end{array}$ & $\begin{array}{ll}- & \begin{array}{l}\text { Increase natural behaviour } \\
\text { (absence of abnormal }\end{array} \\
\text { behaviours, maintenance of } \\
\text { species-typical repertoire) } \\
\text { Maintenance of tame, docile } \\
\text { (not fearful) behaviour } \\
\text { - Increased psychological } \\
\text { well-being of animals } \\
\text { - Improved health (disease } \\
\text { resistance, increased } \\
\text { longevity and reproduction) }\end{array}$ & $\begin{array}{l}\text { - } \quad \text { Need precise specification of what } \\
\text { constitutes failure or success of EE } \\
\text { - Benefits of EE must be } \\
\text { empirically proven } \\
\text { - EE should not decrease animals' } \\
\text { suitability for laboratory life }\end{array}$ & $\begin{array}{l}\text { Recommends against increased } \\
\text { cage sizes }\end{array}$ \\
\hline $\begin{array}{l}\text { Olsson and } \\
\text { Dahlborn, } \\
2002 \text { [37] }\end{array}$ & Mice & $\begin{array}{l}\text { - } " . . . \text { the practice of } \\
\text { modifying housing } \\
\text { conditions in order to } \\
\text { promote natural behaviour } \\
\text { and ameliorate } \\
\text { behavioural problems" } \\
\text { "The term in itself implies } \\
\text { an improvement beyond } \\
\text { the satisfaction of } \\
\text { basic needs" }\end{array}$ & $\begin{array}{ll}\text { - } & \text { Improve animal welfare } \\
\text { - } & \text { Improved biological } \\
\text { - } & \text { Increase natural behaviour } \\
\text { - } & \text { Decrease abnormal behaviour } \\
- & \text { Increase animal's ability to } \\
\text { cope with stressors } \\
\text { - } & \text { Maximise use of } \\
\text { the environment }\end{array}$ & $\begin{array}{l}\text { - } \\
\text { fE should be systematically evaluated } \\
\text { on parameters relevant to } \\
\text { experimental outcomes } \\
\text { Preference studies need to be combined } \\
\text { with studies of motivational strength in } \\
\text { order to draw animal } \\
\text { welfare conclusions } \\
\text { Effects of EE may vary by strain or sex }\end{array}$ & $\begin{array}{ll}- & \text { Nesting material } \\
- & \text { Shelter structures (conditionally) } \\
- & \text { Access to running wheels and } \\
\text { larger or more structured } \\
\text { cages (conditionally) }\end{array}$ \\
\hline $\begin{array}{l}\text { Johnson and } \\
\text { Patterson- } \\
\text { Kane, } \\
2003 \text { [52] }\end{array}$ & Rats & $\begin{array}{l}\text { "... a means of } \\
\text { improving welfare" }\end{array}$ & $\begin{array}{ll}\text { - } & \text { Improve welfare } \\
\text { - } & \text { Correct behavioural } \\
\text { problems such as stereotypies } \\
\text { or apathy }\end{array}$ & $\begin{array}{l}\text { - } \quad \begin{array}{l}\text { EE must be practical in terms of costs } \\
\text { and labour }\end{array} \\
\text { - } \quad \text { EE must be species appropriate } \\
\text { - There may be experimental constraints } \\
\text { such as sterility of the environment or } \\
\text { needing to monitor feed intake } \\
\text { - Laboratory cages are restrictive in size }\end{array}$ & $\begin{array}{l}\text { Foraging EE: } \\
\text { - } \quad \text { Small food particles mixed in } \\
\text { with bedding } \\
\text { - } \quad \text { Mixing food in a dish with } \\
\text { other substrates } \\
\text { - } \quad \text { Giving access to whole food pellets } \\
\text { or variable food types } \\
\text { - } \quad \text { Addition of a shelf in the cage }\end{array}$ \\
\hline
\end{tabular}


Table 1. Cont.

\begin{tabular}{|c|c|c|c|c|c|}
\hline $\begin{array}{l}\text { Author and } \\
\text { Year }\end{array}$ & Species & Definition of EE & Specific Goals of EE & Additional Requirements or Risks of EE & Recommended EE \\
\hline $\begin{array}{l}\text { Hawkins and } \\
\text { Jennings, } \\
2004 \text { [57] }\end{array}$ & Both & $\begin{array}{l}\text { - } \quad \text { "[EE] for rodents is a } \\
\text { positive way to improve } \\
\text { their welfare" } \\
\text { - } \quad \text { Providing good quality } \\
\text { and quantity of space" }\end{array}$ & - $\quad$ Improve welfare & 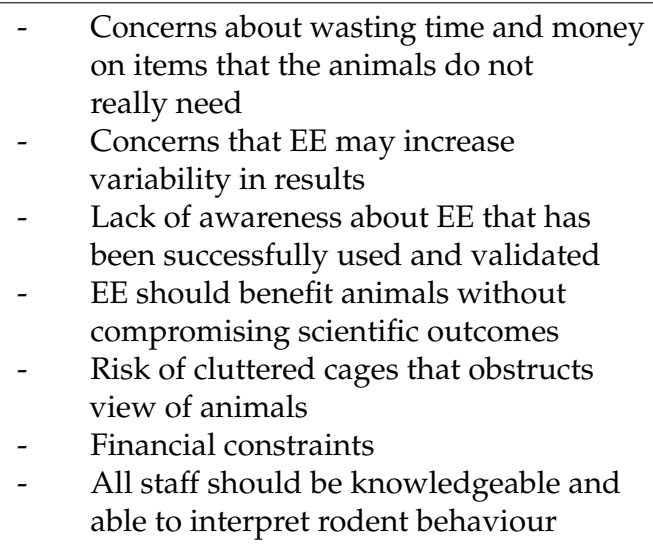 & $\begin{array}{ll}- & \text { Social housing } \\
- & \text { Enough space for exercise and } \\
\text { - } & \text { provision of EE } \\
\text { - } & \text { Sough cage height to rear } \\
- & \text { Adequate depth of appropriate } \\
& \text { substrate } \\
- & \text { Gnawing object } \\
- & \text { Shelter/nest boxes } \\
- & \text { Nesting material } \\
- & \text { Appropriate light levels } \\
- & \text { Foraging opportunities }\end{array}$ \\
\hline $\begin{array}{l}\text { Key, } \\
2004 \text { [58] }\end{array}$ & Both & $\begin{array}{l}\text { " }[\mathrm{EE}] \text { is the alteration } \\
\text { of animals' } \\
\text { microenvironments to } \\
\text { provide them with the } \\
\text { opportunity to perform } \\
\text { species-specific behaviours } \\
\text { that we perceive as positive, } \\
\text { while reducing } \\
\text { abnormal behaviours" }\end{array}$ & $\begin{array}{ll}\text { - } & \text { Improve animal welfare } \\
\text { - } & \text { Increase species-typical } \\
\text { behaviours } \\
\text { - } \quad \begin{array}{l}\text { Decrease stereotypic } \\
\text { behaviours }\end{array}\end{array}$ & $\begin{array}{ll}\text { - } & \text { EE should be proven effective by } \\
\text { statistically significant increase in } \\
\text { positive behaviours, together with } \\
\text { reduction in abnormal behaviours } \\
\text { - } \quad \text { Risk of decreasing usable cage space } \\
\text { - } \quad \text { EE should not cause unacceptable } \\
\text { increases in variability } \\
\text { - } \quad \text { EE should be practical to use } \\
\text { - } \quad \text { EE should be inexpensive }\end{array}$ & $\begin{array}{l}\text { For both: } \\
\text { - } \quad \begin{array}{l}\text { Group-housing of rats and female } \\
\text { mice (male mice conditionally) }\end{array} \\
\text { - } \quad \text { Nesting material } \\
-\quad \text { Nest boxes } \\
\text { - } \quad \text { Foraging opportunities } \\
\text { For rats: } \\
\text { - } \quad \text { Larger and more complex cages for } \\
\text { groups of rats } \\
\text { For mice: } \\
\text { - } \quad \begin{array}{l}\text { Plastic huts are recommended over } \\
\text { wooden or disposable shelters }\end{array}\end{array}$ \\
\hline
\end{tabular}


Table 1. Cont.

\begin{tabular}{|c|c|c|c|c|c|}
\hline $\begin{array}{l}\text { Author and } \\
\text { Year }\end{array}$ & Species & Definition of EE & Specific Goals of EE & Additional Requirements or Risks of EE & Recommended EE \\
\hline $\begin{array}{l}\text { Ottesen et al., } \\
2004 \text { [59] }\end{array}$ & Both & No definition provided & 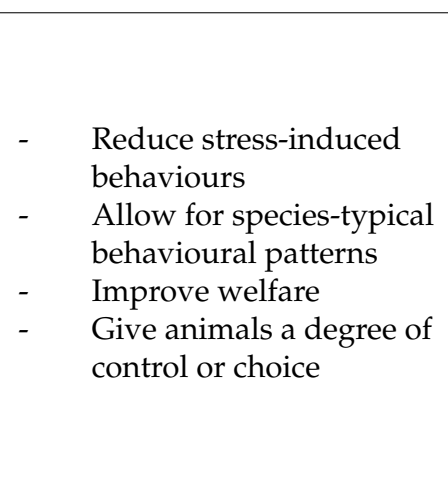 & 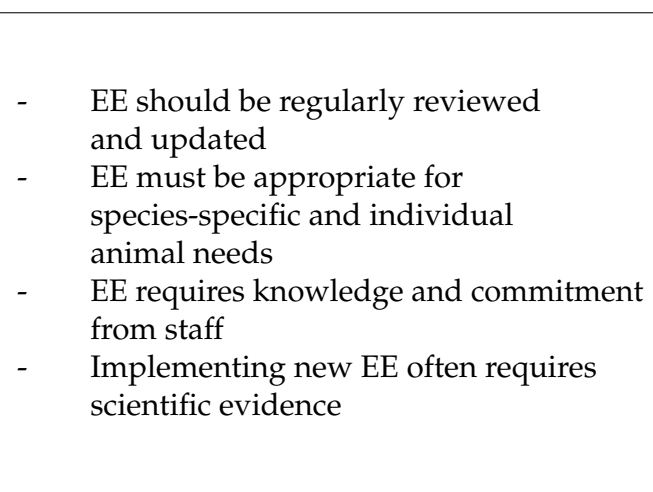 & $\begin{array}{ll}\text { For rats: } \\
\text { - } & \text { Social housing } \\
- & \text { Structured environment with } \\
& \text { increased space, especially vertical } \\
& \text { space for rearing } \\
- & \text { Gnawing and digging } \\
& \text { opportunities } \\
\text { For mice: } & \\
- & \text { Social housing (conditionally) } \\
- & \text { Nesting material } \\
- & \text { Access to darkness } \\
- & \text { Foraging opportunities }\end{array}$ \\
\hline $\begin{array}{l}\text { Patterson- } \\
\text { Kane, } \\
2004 \text { [60] }\end{array}$ & Rats & $\begin{array}{l}\text { - } \text { "It has been thoroughly } \\
\text { demonstrated that barren } \\
\text { housing conditions impair } \\
\text { rats' physical and } \\
\text { behavioural systems, for } \\
\text { example, by having effects } \\
\text { on brain morphology, levels } \\
\text { of fear, and performance on } \\
\text { cognitive tests ... "[EE]" } \\
\text { research attempts to } \\
\text { mitigate this damage and to } \\
\text { improve animal welfare } \\
\text { by modifying } \\
\text { laboratory caging" }\end{array}$ & - $\quad$ Improve animal welfare & $\begin{array}{ll}- & \text { Limited resources (e.g., staff time, } \\
\text { financial costs) } \\
\text { - } \quad \text { Introduction of confounding variables } \\
\text { and potential for increased variability } \\
\text { - } \quad \text { Risks to animal health } \\
\text { - } \quad \text { EE should have empirically } \\
\text { proven benefits } \\
\text { - } \quad \text { EE needs to be tailored to meet animal } \\
\text { needs as well as the requirements of } \\
\text { the research } \\
\text { - } \quad \text { EE should not negatively impact } \\
\text { research goals or economic viability } \\
\text { of research } \\
\text { Biases of personnel may influence EE use } \\
\text { - } \quad \text { EE should be commercially available }\end{array}$ & $\begin{array}{l}\text { - } \quad \text { Social housing (groups larger } \\
\text { than 2) } \\
\text { - } \quad \text { Larger cages } \\
\text { - } \quad \text { Solid, opaque shelters in the form } \\
\text { of nest boxes rather than tunnels } \\
\text { - Comfortable bedding and paper } \\
\text { nesting material }\end{array}$ \\
\hline
\end{tabular}


Table 1. Cont.

\begin{tabular}{|c|c|c|c|c|c|}
\hline $\begin{array}{l}\text { Author and } \\
\text { Year }\end{array}$ & Species & Definition of EE & Specific Goals of EE & Additional Requirements or Risks of EE & Recommended EE \\
\hline $\begin{array}{l}\text { Sørensen et al., } \\
2004 \text { [61] }\end{array}$ & Rats & $\begin{array}{l}\text { "Enhancing the complexity } \\
\text { of the environments of } \\
\text { captive animals is often } \\
\text { referred to as [EE], and } \\
\text { aims to have positive effects } \\
\text { on the animals' well-being" }\end{array}$ & $\begin{array}{ll}\text { - } & \text { Increase welfare } \\
\text { - } & \text { Allow animals to perform a } \\
\text { range of species-specific } \\
\text { behaviours }\end{array}$ & $\begin{array}{ll}\text { - } & \text { EE may cause increased variability } \\
\text { - } & \text { Cost-benefit analysis should include } \\
\text { welfare benefits of EE vs. harms caused } \\
\text { by the experimental procedures involved } \\
\text { - } \quad \text { EE can make standardisation difficult } \\
\text { - } \quad \text { EE may increase aggression } \\
\text { - } \quad \text { EE should be strain, age, and } \\
\text { size appropriate }\end{array}$ & $\begin{array}{ll}\text { - } & \text { Social companions } \\
\text { - } & \text { Variable cage heights } \\
- & \text { Shelters } \\
\text { - } & \text { Soft bedding }\end{array}$ \\
\hline $\begin{array}{l}\text { Van de } \\
\text { Weerd et al., } \\
2004[53]\end{array}$ & Both & $\begin{array}{l}\text { - }[\mathrm{EE}] \text { strategies, which aim } \\
\text { to improve the housing } \\
\text { conditions of laboratory } \\
\text { animals, are viewed } \\
\text { as refinement" }\end{array}$ & Enhance animal welfare & $\begin{array}{ll}\text { - } & \text { EE may increase variation and number } \\
\text { of animals used } \\
\text { - } & \text { Effects of EE should not be generalised } \\
\text { - } & \text { EE should be species, strain, and } \\
\text { sex appropriate }\end{array}$ & $\begin{array}{ll}- & \text { Nesting material } \\
- & \text { Shelters (conditionally) } \\
- & \text { Social housing; for male mice, } \\
& \text { housing in groups of } 3 \text { with } \\
& \text { provision of nesting material }\end{array}$ \\
\hline $\begin{array}{l}\text { Baumans, } \\
2005 \text { [62] }\end{array}$ & Both & $\begin{array}{l}\text { - "...any modification in the } \\
\text { environment of captive } \\
\text { animals that seeks to } \\
\text { enhance its physical and } \\
\text { psychological well-being by } \\
\text { providing stimuli meeting } \\
\text { the animal's } \\
\text { species-specific needs" } \\
\text { "[EE] applies to } \\
\text { heterogenous methods of } \\
\text { improving animal welfare } \\
\text { and includes everything } \\
\text { from social companionship } \\
\text { to toys" }\end{array}$ & 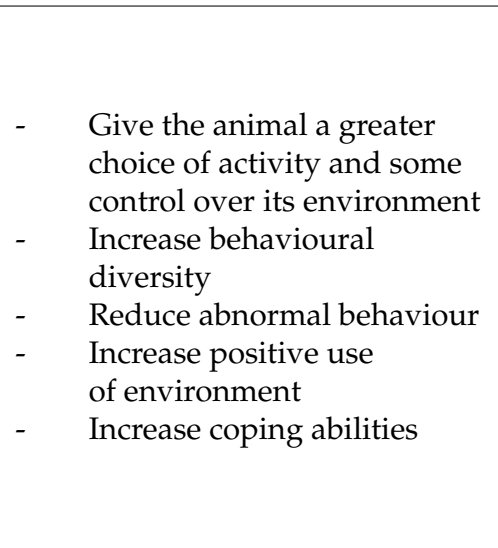 & $\begin{array}{l}\text { - } \quad \begin{array}{l}\text { EE should pose no risk to animals } \\
\text { or humans } \\
\text { - }\end{array} \text { EE should not cause undesirable effects } \\
\text { on experiments } \\
\text { - } \quad \begin{array}{l}\text { EE should not increase the number of } \\
\text { animals used }\end{array} \\
\text { - } \quad \text { EE should be scientifically tested prior } \\
\text { to use } \\
\text { - } \quad \text { Staff must be motivated, educated, and } \\
\text { empowered to implement EE } \\
\text { - } \quad \begin{array}{l}\text { EE must be described sufficiently } \\
\text { in publications }\end{array} \\
\text { - }\end{array}$ & $\begin{array}{ll}\text { For both: } \\
-\quad \text { Social housing } \\
-\quad \text { Structural complexity in the cage } \\
\text { (e.g., shelter or cage divider) } \\
\text { allowing for a level of } \\
\text { environmental control } \\
\text { - } \quad \text { Nesting material } \\
\text { For rats: } \\
-\quad \text { Nest box } \\
-\quad \text { Opportunity to dig and gnaw } \\
-\quad \text { Foraging opportunities }\end{array}$ \\
\hline
\end{tabular}


Table 1. Cont.

\begin{tabular}{|c|c|c|c|c|c|}
\hline $\begin{array}{l}\text { Author and } \\
\text { Year }\end{array}$ & Species & Definition of EE & Specific Goals of EE & Additional Requirements or Risks of EE & Recommended EE \\
\hline $\begin{array}{l}\text { Bayne, } \\
2005 \text { [50] }\end{array}$ & Both & $\begin{array}{l}\text { - } \text { "[EE] is generally } \\
\text { considered to imply an } \\
\text { increase in the complexity } \\
\text { of the environment in } \\
\text { which the animal lives, } \\
\text { with the goal of enhancing } \\
\text { the animal's welfare" } \\
\text { "... can encompass the } \\
\text { variety of food items } \\
\text { offered to the animal; } \\
\text { whether or not the animal } \\
\text { is housed in a bedded cage } \\
\text { (i.e., rodents); and } \\
\text { additional "structural" } \\
\text { en-hancements such as } \\
\text { nest-building mate-rials, } \\
\text { shelves / perches, hiding } \\
\text { areas, ma-nipulanda (toys), } \\
\text { exercise wheels, } \\
\text { climbing/swinging } \\
\text { apparatuses, water features, } \\
\text { access to the outdoors, and } \\
\text { much more" }\end{array}$ & Enhance animal welfare & $\begin{array}{l}\text { - Safety of the animal and the staff should } \\
\text { be considered } \\
\text { - EE must have a demonstrable beneficial } \\
\text { effect on the animal } \\
\text { - Effects of EE may impact experiments or } \\
\text { introduce variables to experiments }\end{array}$ & No specific recommendations \\
\hline $\begin{array}{l}\text { Benefiel et al., } \\
2005 \text { [63] }\end{array}$ & Both & $\begin{array}{l}\text { - } \ldots \text { an increase in the } \\
\text { complexity or naturalness } \\
\text { of an enclosure with the } \\
\text { goal of improving } \\
\text { animal welfare" }\end{array}$ & $\begin{array}{l}\text { - Improve animal health, } \\
\text { fitness, or reproduction } \\
\text { - } \quad \text { Improve animal welfare }\end{array}$ & $\begin{array}{ll}\text { - } & \text { Financial cost } \\
\text { - } & \text { EE should not compromise } \\
\text { research outcomes } \\
\text { - } & \text { EE should not compromise animal } \\
\text { health or well-being } \\
\text { - } \quad \text { Animal preferences should not be used } \\
\text { as the basis for EE decisions } \\
\text { - } \\
\text { Potential for increased variability in } \\
\text { research outcomes }\end{array}$ & - $\quad$ No specific recommendations \\
\hline
\end{tabular}


Table 1. Cont.

\begin{tabular}{|c|c|c|c|c|c|}
\hline $\begin{array}{l}\text { Author and } \\
\text { Year }\end{array}$ & Species & Definition of EE & Specific Goals of EE & Additional Requirements or Risks of EE & Recommended EE \\
\hline $\begin{array}{l}\text { Hutchinson et al., } \\
2005 \text { [64] }\end{array}$ & Both & $\begin{array}{l}\text { - "A method to improve } \\
\text { quality of life" } \\
\text { "In addition to social } \\
\text { activities, [EE] can be } \\
\text { achieved by allowing and } \\
\text { promoting physical } \\
\text { exercise, foraging, } \\
\text { manipulative and cognitive } \\
\text { activities, as relevant to the } \\
\text { species concerned" }\end{array}$ & $\begin{array}{l}\text { - Provide animals with } \\
\text { opportunities to express } \\
\text { species-typical behaviours } \\
\text { Enhance physical and } \\
\text { mental health }\end{array}$ & $\begin{array}{l}\text { - } \quad \begin{array}{l}\text { Risk of impacting experimental design } \\
\text { or outcomes }\end{array} \\
\text { - } \quad \begin{array}{l}\text { EE may have different impacts } \\
\text { depending on species, strain, and age } \\
\text { - }\end{array} \text { Practical considerations (ease of } \\
\text { use, safety) } \\
\text { - } \quad \text { EE must be affordable } \\
\text { - } \quad \text { Animal preference data should be linked } \\
\text { with other measures of well-being to } \\
\text { draw conclusions about EE } \\
\text { - Animal care staff must be } \\
\text { knowledgeable about natural behaviour } \\
\text { of the species }\end{array}$ & $\begin{array}{l}\text { For both: } \\
-\quad \text { Social housing } \\
\text { For rats: } \\
-\quad \text { Structural enrichment } \\
\quad \text { (conditionally) } \\
\text { For mice: } \\
-\quad \text { Nesting material } \\
-\quad \text { Recommend against } \\
\quad \text { "superenrichment" }\end{array}$ \\
\hline $\begin{array}{l}\text { Smith and } \\
\text { Corrow, } \\
2005 \text { [65] }\end{array}$ & Both & $\begin{array}{l}\text { - } \quad \text { EE is often defined as a } \\
\text { "change to the } \\
\text { environment" } \\
\text { "[EE] is increas-ingly } \\
\text { appreciated as a way to } \\
\text { im-prove the well-being of } \\
\text { rodents, providing them } \\
\text { with oppor-tunities for } \\
\text { species-specific behaviours } \\
\text { that might be available to } \\
\text { them in the wild" } \\
\text { "[EE] can be as simple as } \\
\text { adding a tissue or a } \\
\text { particular type of bedding } \\
\text { material to the cage, or as } \\
\text { complex as adding devices } \\
\text { such as shelters, running } \\
\text { wheels, blocks for chewing, } \\
\text { or plastic tubes" }\end{array}$ & 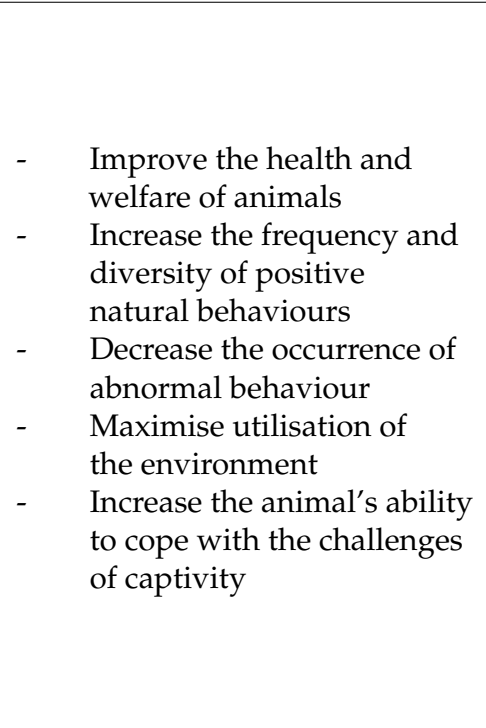 & $\begin{array}{l}\text { - Potential for increase in experimental } \\
\text { variability; EE should not cause } \\
\text { significantly more animals to be needed } \\
\text { EE changes should not affect the } \\
\text { dimensions of the caging systems } \\
\text { currently in use } \\
\text { - } \quad \text { EE should be cost-effective } \\
\text { - } \quad \text { EE must be strain and sex appropriate }\end{array}$ & $\begin{array}{l}\text { For rats: } \\
-\quad \text { social housing } \\
\text { For mice: } \\
-\quad \text { nesting material }\end{array}$ \\
\hline
\end{tabular}


Table 1. Cont.

\begin{tabular}{|c|c|c|c|c|c|}
\hline $\begin{array}{l}\text { Author and } \\
\text { Year }\end{array}$ & Species & Definition of EE & Specific Goals of EE & Additional Requirements or Risks of EE & Recommended EE \\
\hline $\begin{array}{l}\text { Balcombe, } \\
2006[66]\end{array}$ & Both & No definition provided & $\begin{array}{l}\text { Allow for normal or } \\
\text { motivated behaviours }\end{array}$ & $\begin{array}{l}\text { - Practical challenges in changing existing } \\
\text { housing systems } \\
\text { - } \quad \text { Financial costs }\end{array}$ & $\begin{array}{ll}\text { - } & \text { Social housing for mice and rats; } \\
\text { aggressive male mice may benefit } \\
\text { from creative husbandry solutions } \\
\text { rather than isolation } \\
\text { - } \quad \text { Increased space } \\
\text { - } \quad \text { Nesting material } \\
\text { - } \quad \text { Shelter }\end{array}$ \\
\hline $\begin{array}{l}\text { Würbel and } \\
\text { Garner, } \\
2007[54]\end{array}$ & Mice & $\begin{array}{l}\text {-We distinguish between } \\
\text { [EE] as an experimental } \\
\text { variable (meaning adding } \\
\text { inanimate and/or social } \\
\text { stimuli to the environment) } \\
\text { and its consequences in } \\
\text { terms of animal welfare, } \\
\text { and use the term beneficial } \\
\text { enrichment for cases where } \\
\text { [EE] results in improved } \\
\text { animal welfare" }\end{array}$ & Improve animal welfare & 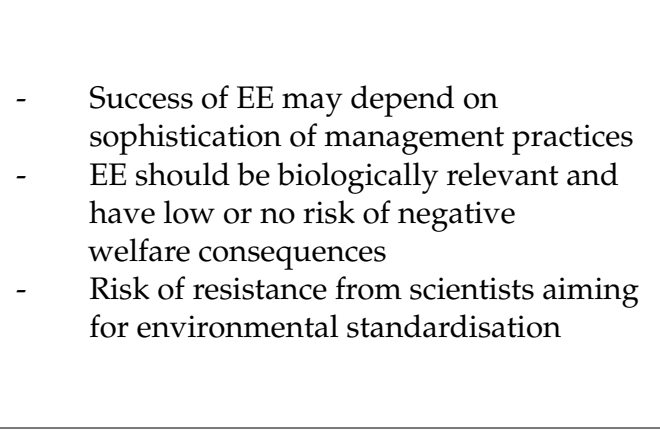 & $\begin{array}{ll}- & \text { Nesting material } \\
- & \text { Shelters (conditionally) } \\
- & \text { Recommend against } \\
& \text { pseudoenrichment (e.g., marbles) }\end{array}$ \\
\hline $\begin{array}{l}\text { Brown, } \\
2009[51]\end{array}$ & Both & $\begin{array}{l}\text { - } \text { "In addition to social } \\
\text { activities, [EE] can be } \\
\text { achieved by allowing and } \\
\text { promoting physical } \\
\text { exercise, foraging and } \\
\text { manipulative and } \\
\text { cognitive activities" }\end{array}$ & $\begin{array}{l}\text { - Promote natural behaviours- } \\
\text { reduce stereotypies }\end{array}$ & $\begin{array}{ll}\text { - } & \text { Dietary or other restrictions of } \\
\text { scientific studies } \\
\text { - } \quad \text { Financial concerns } \\
\text { - } \quad \text { EE needs to be appropriate for the } \\
\text { specific experimental circumstances }\end{array}$ & $\begin{array}{l}\text { Foraging EE: } \\
\text { - } \quad \text { hay cubes, fruit or vegetable-based } \\
\text { treats, and diets consisting of seeds } \\
\text { and grains that can be delivered to } \\
\text { the animals in a variety of ways, } \\
\text { such as within a dry pasta shell or } \\
\text { wooden toy with holes }\end{array}$ \\
\hline
\end{tabular}


Table 1. Cont.

\begin{tabular}{|c|c|c|c|c|c|}
\hline $\begin{array}{l}\text { Author and } \\
\text { Year }\end{array}$ & Species & Definition of EE & Specific Goals of EE & Additional Requirements or Risks of EE & Recommended EE \\
\hline $\begin{array}{l}\text { Simpson and } \\
\text { Kelly, } 2011 \text { [68] }\end{array}$ & Rats & $\begin{array}{l}\text { - }[E E] \text { is a term for exposing } \\
\text { laboratory animals to } \\
\text { physical and/or social } \\
\text { stimulation that is greater } \\
\text { than they would receive } \\
\text { under standard } \\
\text { housing conditions" }\end{array}$ & $\begin{array}{ll}\text { - } & \text { Reduce stereotypies } \\
\text { - } & \text { Improve welfare }\end{array}$ & $\begin{array}{ll}\text { - } & \text { EE should be biologically relevant } \\
\text { - } & \text { EE should be appropriately validated } \\
\text { - } & \text { EE must not increase variability or } \\
\text { increase the number of animals required } \\
\text { in studies } \\
\text { - } \quad \text { EE should be age, strain, and } \\
\text { sex appropriate }\end{array}$ & $\begin{array}{l}\text { - A combination of both social and } \\
\text { physical enrichment elements is } \\
\text { recommended } \\
\text { - } \quad \text { Larger cages } \\
\text { - } \quad \text { Social housing }\end{array}$ \\
\hline
\end{tabular}


Table 1. Cont.

\begin{tabular}{|c|c|c|c|c|c|}
\hline $\begin{array}{l}\text { Author and } \\
\text { Year }\end{array}$ & Species & Definition of EE & Specific Goals of EE & Additional Requirements or Risks of EE & Recommended EE \\
\hline $\begin{array}{l}\text { Baumans and } \\
\text { Van Loo, } \\
2013 \text { [69] }\end{array}$ & Both & $\begin{array}{l}\text { " }[\mathrm{EE}] \text { can be defined as any } \\
\text { modification in the } \\
\text { environment of captive } \\
\text { animals that seeks to } \\
\text { enhance its physical and } \\
\text { psychological well-being by } \\
\text { providing stimuli which } \\
\text { meet the animals' } \\
\text { species-specific needs" }\end{array}$ & $\begin{array}{ll}\text { - } & \text { Provide stimuli beyond } \\
\text { satisfaction of basic needs } \\
\text { - } \quad \text { Benefit animal well-being } \\
\text { and experimental outcomes }\end{array}$ & $\begin{array}{l}\text { - } \quad \text { EE should be practical } \\
\text { - } \quad \text { EE should meet animals' needs } \\
\text { - } \quad \text { EE should be inexpensive } \\
\text { aE should pose no risk to humans, } \\
\text { animals, or the experiment } \\
\text { - } \quad \text { EE should be empirically supported } \\
\text { by research } \\
\text { - } \quad \text { Factors important to the animal, } \\
\text { scientific validity of the animal model, } \\
\text { and the animal facility must be } \\
\text { equally addressed } \\
\text { - Staff must be motivated and educated } \\
\text { Potential for impacts on scientific } \\
\text { outcomes or statistical power }\end{array}$ & $\begin{array}{ll}\text { - } & \text { Nesting material } \\
\text { - } & \text { Chewable items } \\
\text { - } & \text { Opportunities for foraging } \\
\text { Social contact }\end{array}$ \\
\hline $\begin{array}{l}\text { Bayne and } \\
\text { Würbel, } \\
2014 \text { [70] }\end{array}$ & Both & $\begin{array}{l}\text { - } . . . .[E E] \text { has been } \\
\text { described as a means to } \\
\text { increase the amount of time } \\
\text { an animal spends in } \\
\text { species-typical activities } \\
\text { (e.g., foraging, nest } \\
\text { building), with a } \\
\text { concomitant reduction in } \\
\text { time spent expressing } \\
\text { abnormal behaviour such } \\
\text { as stereotypic locomotion } \\
\text { and self-injurious } \\
\text { behaviour" } \\
\text { "... inappropriate } \\
\text { enrichment can induce fear } \\
\text { or stress in an animal, and } \\
\text { thus it is most accurate to } \\
\text { speak in terms of providing } \\
\text { beneficial enrichments, } \\
\text { which improve an } \\
\text { animal's welfare" }\end{array}$ & $\begin{array}{ll}\text { - } & \text { Increase the amount of time } \\
\text { an animal spends in } \\
\text { species-typical activities } \\
\text { - } \quad \text { Improve animal welfare } \\
\text { - } \quad \text { Expand range of } \\
\text { possible behaviours } \\
\text { - } \quad \text { Address or prevent } \\
\text { abnormal behaviour }\end{array}$ & $\begin{array}{l}\text { - } \begin{array}{l}\text { Must consider the safety of the animals } \\
\text { and personnel } \\
\text { - }\end{array} \text { Physical and operational constraints of } \\
\text { laboratory facilities } \\
\text { - } \quad \text { Staff must be knowledgeable } \\
\text { - } \quad \text { EE program should account for age, } \\
\text { strain, and sex of the animals } \\
\text { - } \quad \text { EE should not preclude care staff from } \\
\text { conducting daily husbandry duties } \\
\text { - Need to understand potential } \\
\text { ramifications of EE on the animal's } \\
\text { biology and whether this may have } \\
\text { consequences for research outcomes }\end{array}$ & $\begin{array}{l}\text { For both: } \\
\text { - } \quad \text { Social housing } \\
\text { - } \quad \text { Opportunities for physical and } \\
\quad \text { cognitive activity, such as foraging } \\
\text { - } \quad \text { Shelters } \\
\text { For mice: } \\
\text { - } \quad \text { Nesting material }\end{array}$ \\
\hline
\end{tabular}


Table 1. Cont.

\begin{tabular}{|c|c|c|c|c|c|}
\hline $\begin{array}{l}\text { Author and } \\
\text { Year }\end{array}$ & Species & Definition of EE & Specific Goals of EE & Additional Requirements or Risks of EE & Recommended EE \\
\hline $\begin{array}{l}\text { Jirkof, } \\
2015 \text { [71] }\end{array}$ & Mice & $\begin{array}{l}\text { " } \\
\text { housing efforts in routine } \\
\text { terms of costs and } \\
\text { practicability, less complex } \\
\text { than cage enrichment in } \\
\text { neu-robiology research. } \\
\text { Often these efforts involve } \\
\text { the addi-tion of biologically } \\
\text { relevant features to the } \\
\text { cage, creating a more } \\
\text { natural set-ting, with the } \\
\text { aim of facilitating or } \\
\text { enabling the animals to } \\
\text { engage in } \\
\text { natural behaviours" }\end{array}$ & $\begin{array}{ll}\text { - } & \text { Promote animal welfare } \\
\text { - } & \text { Facilitate natural behaviours } \\
\text { - } & \text { Enhance physical and } \\
& \text { emotional well-being }\end{array}$ & $\begin{array}{ll}\text { - } & \text { EE should not increase variation or } \\
\text { negatively impact experimental results } \\
\text { - } \quad \text { EE should not necessitate increased } \\
\text { animal numbers } \\
\text { - } \quad \begin{array}{l}\text { Effects of EE may be sex and } \\
\text { strain dependent }\end{array}\end{array}$ & $\begin{array}{ll}\text { - } & \text { Familiar environments with stable } \\
\text { social groups whenever possible } \\
\text { (especially females) } \\
\text { - } \\
\text { Recommend evaluation of EE on a } \\
\text { case-by-case basis }\end{array}$ \\
\hline $\begin{array}{l}\text { Bayne, } \\
2018 \text { [72] }\end{array}$ & Mice & $\begin{array}{l}\text { - } \ldots \text { a method to enhance } \\
\text { animal well-being by } \\
\text { providing animals with } \\
\text { sensory and motor } \\
\text { stimulation, through } \\
\text { structures and resources } \\
\text { that facilitate the expression } \\
\text { of species-typical } \\
\text { behaviours and promote } \\
\text { psychological well-being } \\
\text { through physical exercise, } \\
\text { manipulative activities and } \\
\text { cognitive challenges } \\
\text { according to species- } \\
\text { specific characteristics" }\end{array}$ & $\begin{array}{ll}\text { - } & \text { Reduce stereotypic behaviour } \\
\text { - } & \text { Increase expression of } \\
\text { - } & \text { species-typical behaviours } \\
\text { Improve animal welfare }\end{array}$ & $\begin{array}{l}\text { - EE should be implemented with input } \\
\text { from the investigator, the veterinarian, } \\
\text { and husbandry staff } \\
\text { - EE must be thoroughly researched and } \\
\text { evidence-based } \\
\text { - EE should not negatively impact health } \\
\text { or safety of animals } \\
\text { - } \quad \text { EE must be biologically relevant }\end{array}$ & $\begin{array}{ll}\text { - } & \text { Nesting material } \\
\text { - } & \text { Nest boxes/shelter }\end{array}$ \\
\hline
\end{tabular}


Table 1. Cont.

\begin{tabular}{|c|c|c|c|c|c|}
\hline Author and Year & Species & Definition of EE & Specific Goals of EE & Additional Requirements or Risks of EE & Recommended EE \\
\hline $\begin{array}{l}\text { Lewejohann et al., } \\
2020 \text { [73] }\end{array}$ & Mice & $\begin{array}{l}\text { "... improving housing } \\
\text { conditions" }\end{array}$ & $\begin{array}{ll}\text { - } & \text { Enhance animal welfare } \\
\text { - } & \text { Provide opportunities for } \\
\text { species-typical behaviour } \\
\text { - } \quad \text { Provide opportunities } \\
\text { to engage in } \\
\text { rewarding behaviours } \\
\text { - } \\
\text { Reduce boredom }\end{array}$ & $\begin{array}{ll}\text { - } & \text { Financial costs } \\
\text { - } & \text { Need for qualified personnel and } \\
\text { available space } \\
\text { - } \quad \begin{array}{l}\text { Possible interferences with experimental } \\
\text { design or increase in variability of results }\end{array} \\
\text { - } \quad \begin{array}{l}\text { Possible sex differences in how EE } \\
\text { affects the animals }\end{array}\end{array}$ & $\begin{array}{ll}- & \text { Nesting material } \\
- & \text { Burrowing opportunities } \\
- & \text { Gnawing substrate } \\
- & \text { More space to engage in } \\
& \text { locomotory play behaviour } \\
- & \text { Cognitive training }\end{array}$ \\
\hline $\begin{array}{l}\text { Pritchett-Corning, } \\
2020 \text { [74] }\end{array}$ & Both & $\begin{array}{l}\text { - Used the term } \\
\text { en-vironmental } \\
\text { com-plexity (EC) } \\
\text { "[EC] is, by necessity, } \\
\text { defined by comparisons } \\
\text { rather than by a specific } \\
\text { description. Two } \\
\text { boundaries could be } \\
\text { posited: a barren } \\
\text { environment and the } \\
\text { environment as } \\
\text { experienced by wild } \\
\text { animals. In general, } \\
\text { environmental } \\
\text { complexity could be } \\
\text { lumped into standard } \\
\text { enrichment, } \\
\text { super-enrichment, and } \\
\text { semi-naturalistic } \\
\text { environments" }\end{array}$ & 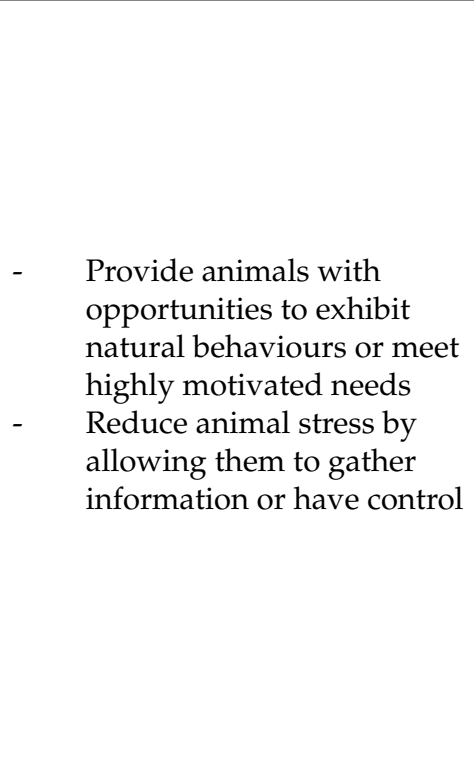 & $\begin{array}{l}\text { - } \quad \begin{array}{l}\text { Assessment of EC should be rigorous } \\
\text { and may need to be repeated due to }\end{array} \\
\text { strain and sex interactions } \\
\text { - } \quad \text { EC should have some relation to a } \\
\text { species' natural environment } \\
\text { - Practical problems, such as lack of space } \\
\text { for larger cages or sourcing and } \\
\text { sanitising of EC objects } \\
\text { - } \quad \text { Potential for injury to animals } \\
\text { - } \quad \text { Increased labour required to maintain } \\
\text { - } \quad \text { Potential to disrupt ongoing research }\end{array}$ & $\begin{array}{l}\text { - } \quad \text { "Standard" EE: cage with bedding, } \\
\text { nesting material, shelter } \\
\text { (conditionally), and a social partner } \\
\text { "Superenriched" environment } \\
\text { should offer greater variety of } \\
\text { objects, more space, more } \\
\text { social partners } \\
\text { "Semi-naturalistic" enclosures } \\
\text { should offer more opportunities for } \\
\text { natural behaviours; may allow } \\
\text { outdoor access, orders of } \\
\text { magnitude larger than other } \\
\text { housing options } \\
\text { Further efforts toward working } \\
\text { with rodents in semi-naturalistic } \\
\text { settings should be pursued }\end{array}$ \\
\hline
\end{tabular}


Table 1. Cont.

\begin{tabular}{|c|c|c|c|c|c|}
\hline $\begin{array}{l}\text { Author and } \\
\text { Year }\end{array}$ & Species & Definition of EE & Specific Goals of EE & Additional Requirements or Risks of EE & Recommended EE \\
\hline $\begin{array}{l}\text { Kentner et al., } \\
2021 \text { [46] }\end{array}$ & Both & $\begin{array}{l}\text { - }[\mathrm{EE}] \text { is one form of } \\
\text { complexity that includes } \\
\text { physical, sensory, cognitive, } \\
\text { and/or social stimulation } \\
\text { which provides an } \\
\text { enhanced living experience } \\
\text { to laboratory animals, } \\
\text { relative to standard } \\
\text { housing conditions" }\end{array}$ & $\begin{array}{ll}\text { - } & \text { Promote natural behaviours } \\
\text { - } & \text { Promote typical } \\
\text { brain functioning } \\
\text { - } \quad \begin{array}{l}\text { Provide an enhanced living } \\
\text { experience to animals }\end{array}\end{array}$ & $\begin{array}{ll}\text { - } & \text { Availability of resources (financial, } \\
\text { physical space) } \\
\text { - } & \text { Feasibility (e.g., personnel constraints) } \\
\text { - } & \text { Effects of EE may vary with species, age, } \\
\text { or sex } & \\
\text { - } & \text { Changing EE standards will require } \\
\text { changes in mindsets of institutions, } \\
\text { scientists, and funding bodies } \\
\text { - Concerns about variability }\end{array}$ & $\begin{array}{ll}\text { - } & \text { Social housing } \\
\text { - } & \text { Use larger cages that would take } \\
\text { up the same space as several } \\
\text { smaller cages to house } \\
\text { larger groups } \\
\text { - } \quad \text { Regularly rotating EE for novelty }\end{array}$ \\
\hline
\end{tabular}




\subsection{Environmental Enrichment Definitions and Goals}

Most articles acknowledged that the blanket use of the terms "enriched" and "enrichment" should be avoided, but alternative terminology was not agreed upon. Within the articles reviewed, six alternatives were suggested to replace the term "environmental enrichment". Olsson and Dahlborn [37] (p. 246) suggested "changes to or modifications of the environment or housing conditions," to avoid implying that all modifications are positive for animals. Similarly, Benefiel et al. [63] (p. 96) proposed the term "housing supplementation" as an alternative to enrichment, again avoiding implications that all changes benefit the animals. Baumans and Van Loo [69] (p. 26) used the term "environmental refinement" to indicate the ongoing process of providing more than just the basic needs of animals, highlighting that the term "enrichment" is sometimes taken to imply that animals are provided with luxuries. Pritchett-Corning [74] (p. 239) used the descriptive (rather than evaluative) term "environmental complexity", explaining that this ranges from barren to naturalistic conditions, and that varying categories of environmental enrichment (standard, superenriched, and semi-naturalistic) exist within this range. Sørensen et al. [61] used the terms enrichment and complexity interchangeably. Würbel and Garner [54] (p. 3) differentiated between possible enrichment outcomes, using the term "beneficial enrichment" for enrichment that is biologically relevant and improves animal welfare, and referring to enrichment attempts that are not biologically relevant or potentially harmful as "pseudoenrichment." "Superenrichment" was defined separately from environmental enrichment in two articles, without consensus $[64,74]$. Our own view is that despite the shortcomings of the term, "environmental enrichment" is so engrained in the literature that it is unlikely that any alternative will soon replace it. Going forward, we suggest that the term "enriched" should be accompanied by an explicit description, including what a chosen strategy is aiming to achieve and criteria for success.

Overall, definitions were largely focused on what enrichment should achieve; few described what enrichment should resemble. Some mentioned the theme of increasing environmental complexity or naturalness, but were not prescriptive as to what this should entail. Three articles did not provide a definition of environmental enrichment.

The most common elements of definitions were that enrichment changes the environment to improve animal welfare, facilitate natural or species-typical behaviours, and increase engagement or stimulation. Improving animal welfare and increasing natural behaviour were also the most commonly mentioned goals of enrichment (mentioned in 23 and 20 articles, respectively). These are different but potentially overlapping aims, depending on how animal welfare is conceived. Much like environmental enrichment, animal welfare does not have one universally agreed upon definition or framework. For example, Fraser et al. [75] consider welfare as three overlapping spheres: natural living, biological functioning, and affective states (emotions or feelings), but others have emphasised biological functioning [76] or fulfilment of an animal's evolutionary nature [77]. Dawkins [78] has suggested that animal welfare is the combination of health and what animals want, precluding naturalness as inherently important to welfare, and rather favouring animal preferences and motivation. Other attributes, such as the ability for animals to exercise agency, have also gained traction in recent years $[79,80]$. Thus, improving welfare can mean different things to different people.

Several authors cited a definition describing enrichment as an improvement in biological functioning as a result of environmental changes [36], indicating that health and biological functioning are central to their idea of welfare. Reviewed articles mentioned a variety of goals that fit under the umbrella of animal welfare and may be indicative of different frameworks or priorities: improving health or biological functioning (eight articles), improving psychological well-being (eight articles), increasing ability to cope with stressors (four articles), providing choice or control (three articles), and reducing boredom (two articles). Other definitions specified that enrichment is a method to decrease abnormal or stereotypic behaviours, or that enrichment provides animals with increased coping abilities or cognitive opportunities. 
According to certain conceptions of welfare, naturalness, or the ability to express natural behaviours is an inherent concern, but for others the expression of natural behaviour may only be of value if it contributes to improving other components of animal welfare such as affective states or biological functioning (discussed in [81]). For example, Bracke and Hopster proposed the following instrumental conception of natural behaviour as "behaviour that animals tend to perform under natural conditions, because it is pleasurable and promotes biological functioning" [15] (p. 80). Newberry [36] suggested that the functionality and adaptiveness of a behaviour should be emphasised, while Mench [82] suggested that we should focus on identifying the consequences of a behaviour. If more instrumental conceptions are adopted, then understanding how specific behaviours contribute to welfare is important. However, at least for some, living a natural life may be viewed as inherent to good welfare [83].

In captive settings at least, some "unnatural" behaviours may promote positive affective states or biological functioning, while some more natural behaviours may have the opposite effect. As one example, neuroscientists trained rats to drive a car (to measure the effects of environmental enrichment on learning abilities), and noted that the training process seemed to serve as a form of enrichment for all rats [84]. Some articles stated more specifically that a goal of enrichment is to increase positive natural behaviours $[7,37,58]$. One article suggested that enrichment should strive to keep animals docile or tame rather than encouraging behaviours typical of wild animals given that some of these behaviours, such as avoidance of humans or reactivity to handling, are seen as unsuitable for life in the laboratory [56]. We suggest that enrichment strategies that increase behavioural diversity (see [85]) or provide increased agency (i.e., the ability to exert control over their environment or make choices) will be instrumentally beneficial to the welfare of laboratory animals regardless of their perceived naturalness. We also recommend that authors be specific when describing which behaviours they are attempting to elicit (or supress) and why they believe this to be important for the animal.

Articles often specified that enrichment should decrease stereotypic or undesirable behaviours (13 articles), raising the question of whether enrichment is seen as more of a preventative tool or a treatment for these behaviours. Considering the reduction of stereotypic behaviour as a key goal of enrichment may lead some to conclude that environmental conditions are adequate when stereotypic behaviours are absent or rare (e.g., [7,56,63]), failing to recognise that a lack of abnormal behaviours is not evidence of good welfare $[2,86]$. Providing an environment that reduces the development of stereotypies is likely to be good for welfare, but once these behaviours develop, they can persist if the enrichment does not address the underlying motivation [87].

\subsection{Commonly Recommended Rodent Enrichment Strategies}

Some earlier authors were sceptical regarding implementation of enrichment, promoting a more cautious approach to even basic cage modifications (e.g., [7,56,63]); however, more supportive views also existed in earlier years (e.g., $[13,55,57])$, so it is unclear if perceptions have changed consistently over time. That said, more recent publications generally support the provision of more extensive environmental enrichment for laboratory rodents [46,73,74]; some more basic recommendations, like solid cage floors [55,57], were present only in earlier reviews (likely because wire flooring is no longer common). Three articles made no overall recommendations due to the lack of consensus or the perceived need for more research. Some authors may have excluded some more popular husbandry strategies (such as social housing) from their recommendations because they considered these to be a different type of husbandry component (i.e., social rather than environmental), or a standard practice rather than an improvement upon current conditions.

For rats, social housing was recommended in 17 articles, followed by larger/higher cages (10 articles), nesting material (nine articles), shelters/nest boxes (11 articles), and opportunities to forage (seven articles) or gnaw (six articles). Less commonly recommended were soft or deep bedding (four articles), digging opportunities (two articles), solid flooring 
or a shelf in the cage (three articles), regular introduction of novelty (one article), auditory enrichment (one article), appropriate lighting (one article), and hard pelleted food (one article). One article recommended against increasing cage sizes, and another recommended against "superenriched" conditions.

For mice, nesting material was most often recommended (18 articles), followed by social housing (14 articles), shelters/nest boxes (12 articles), foraging opportunities (seven articles), and larger cages (six articles). Other recommendations included gnawing opportunities (four articles), appropriate lighting (two articles), burrowing (one article), climbing opportunities (one article), positive reinforcement training (one article), and auditory enrichment (one article). Running wheels were only conditionally recommended (one article), as were several other forms of enrichment due to concerns about the potential for aggression or individual differences between animals. One article recommended against marbles (as an example of pseudoenrichment), one recommended against larger cages, and one argued against the use of "superenriched" conditions. Support for social housing and larger cages (compared to the current conventional cage sizes) was noted more often for rats than for mice; this may be related to the relatively more restrictive dimensions of existing rat cages, or concerns about mouse aggression in larger cages. Several recommendations were made conditionally; for example, many forms of enrichment were recommended for female mice but not for males due to sex-specific differences in outcomes.

Different authors may have conceptualised categories of enrichment differently. For example, some authors specified that rodents should be provided with shelters, while others used the term nest box, but often too little detail was provided to determine if the terms were being used synonymously. The common practice of providing rats with a tunnel or section of PVC pipe may not be in line with recommendations if authors consider nest boxes and/or shelters to be structurally different from open-ended tunnels-one article specifically recommended against the use of tunnels as shelters (likely because rats do not prefer open-ended tunnels [88]). Such discrepancies highlight the need for specificity in enrichment descriptions.

Discriminating between different applications of enrichment (i.e., a housing refinement vs. an experimental treatment for biomedical or neuroscience research) is important given that there is some discrepancy between what is commonly applied in experiments and what is considered functionally appropriate for rodents. "Toys" (typically used when referring to a wide range of inanimate objects in a variety of shapes and colours) are commonly used in enrichment research [46,68]. Some studies have included billiard balls [89] or checkers tiles and ping-pong balls [90] in their "enriched" conditions. It is worth noting that toys were not generally recommended for rodents in the articles we reviewed, and have been criticised as functionally irrelevant [36]. Another term, manipulanda (defined as "any objects that can be altered by an animal or encourage it to engage in fine motor movements" [64] (p. 151)), is more commonly used in the enrichment literature and tends to include examples of functional items which have been recommended for rodents, such as gnawing devices.

Some enrichment methods are well studied and were frequently endorsed in review articles. We suggest that several of these more frequently endorsed elements (i.e., social housing, nesting material, shelters, foraging opportunities) are now sufficiently established that they should be regarded as basic to good rodent housing conditions rather than "enriched", or that systems that fail to include these features be considered impoverished. Others have suggested that conventional housing should be more formally recognised as a stressful laboratory procedure [21]. Such framing may help motivate change in laboratories that until now have been unable or unwilling to include these features.

\subsection{Risks or Requirements of Enrichment}

Most articles in Table 1 described perceived barriers to implementing enrichment, which we have summarised as anything identified as a risk (i.e., a potentially negative outcome) or a requirement that must be met for enrichment to be implemented. The most 
often cited risks and requirements were (followed by the number of articles citing this theme): enrichment programs must account for biological differences (e.g., species, strain, age, or sex; 16); financial constraints (14); practical issues (e.g., increased labour; 14); risks of increased variability (14); risks of altered research outcomes (13); enrichment must have empirically proven benefits (12); and risks to animal health or safety (12). Each of these risks or requirements are discussed in more detail in the sections that follow.

\subsubsection{Enrichment Programs Must Account for Biological Differences}

Most articles stated that enrichment must be assessed for a range of factors such as species, age, strain, and sex to ensure that it is biologically appropriate. Indeed, reactions to enrichment may vary according to genetic strain [91] or sex (especially for mice, discussed in Section 3.3.7). Related to this notion, some articles promoted assessment of enrichment on a case-by-case basis instead of making broad recommendations [7,50,71]. While this approach might cater to biological or individual differences, it would also increase the workload related to enrichment, which was commonly cited as something to avoid. Another risk of a case-by-case approach is that the adoption of any enrichment could then be considered inappropriate by default until its effectiveness has been researched with the strain, sex, disease, etc. of interest. As outlined above, we suggest that widely studied housing features could be universally applied as the default option unless there is evidence to justify contraindication in specific instances. Minimum housing guidelines have proven to be important in the adoption of basic enrichment for rodents, and some technicians in the UK have suggested that more specific regulations could help to overcome barriers [92].

\subsubsection{Financial Constraints}

The need for enrichment programs to be inexpensive or to make use of existing materials was emphasised in several articles. One article suggested that it would be unfair for facilities to bear the burden of investing in new housing infrastructure [65], but it is unclear who should bear this burden instead. Another article argued that funds should be made available to establish more complex housing for lab animals, but did not specify from whom [46]. In Canada, guidelines state that the convenience or cost of enrichment (either financially or in terms of labour) should not be the deciding factor regarding whether to provide enrichment [93], but a Canadian survey found that the majority of researchers considered financial costs in animal welfare decisions [94]. This gap suggests that more specific guidance is needed by regulators to reduce the risk that refinements are dismissed because of financial concerns.

In animal agriculture, the notion that improvements in animal welfare must be balanced against economic costs is common [95]. Improved welfare on farms can sometimes result in increased productivity (e.g., through improved product quality or decreased mortality [96]). Similar opportunities may be possible in laboratory animal research if improved welfare also improves the quality (e.g., reproducibility or validity) of research findings, as suggested in several articles [46,53,54,70,72].

\subsubsection{Practical Issues}

Most articles raised concerns about the practicality of enrichment. This may be in contention with regulatory sentiments that "decisions to implement enrichment strategies should not be based on convenience where the result is to the detriment of animal welfare" [93], (p. 20). Concerns about practicality are not unique to rodents; for example, Stevens et al. [97] acknowledged the commonly raised practical concerns surrounding the implementation of enrichment in zebrafish facilities, such as increased costs or labour. Lack of time is one of the most often reported barriers to enrichment [98]. However, other work has shown that staff generally want to implement more enrichment for animals in their care, and personnel who reported less enrichment use, or the desire to provide more enrichment to their animals, also reported higher rates of burnout [99]. Animal care staff in one study reported a slight increase in workload when shelters and nesting material were introduced 
in their animal units, but their overall impression of the enrichment was positive [100]. Lack of time has also been identified as a major barrier to the adoption of non-aversive handling methods for laboratory mice [101] and refined euthanasia methods [102]. Likewise, in the zoo community, technicians often feel constrained by lack of time [103] or lack of institutional support rather than lack of personal motivation to implement enrichment [104]. Despite being viewed by zoo professionals as an essential husbandry practice, enrichment is often treated as a luxury due to practical barriers to its implementation [104].

Practical issues such as lack of time may require creative solutions. For example, one university implemented a program to reduce time spent on cage cleaning, streamlining the process and freeing up approximately $35 \mathrm{~min} / \mathrm{d}$ of technician time that could be spent elsewhere [105]. Similar initiatives across animal research facilities may enable staff to spend more time engaging in enrichment activities. Opportunities to provide enrichment may have additional value in the form of increased job satisfaction [106] and reduced compassion fatigue for personnel working with laboratory animals.

\subsubsection{Risk of Increased Variability}

The risk of increased variability was identified in approximately half of the reviewed articles. Increasing variability was often seen to conflict with the goal of Reduction (assuming that research under more complex environmental conditions necessitates larger sample sizes). Several articles in Table 1 suggested that the risk of increased variation was low. One article concluded that enrichment does not generally increase variation in results, although this can depend on factors such as strain, experimental parameters, and enrichment provided [53]. Another concluded that enrichment can be used without increasing within-experiment variation so long as it is species-appropriate and does not act as a stressor (otherwise variation may increase) [70]. A systematic review and meta-analysis of 281 rodent enrichment studies concluded that complex housing does not make results any more variable in comparison to conventional laboratory housing [46]. Another recent systematic review of rodents induced with stress-sensitive diseases found no effect of housing conditions on variation [21].

A series of empirical studies have largely failed to show an increase in variability resulting from enrichment. In a study using three different housing conditions, Augustsson et al. [107] found that genetic strain of the mouse had the biggest impact on variation in light-dark box behaviour, body weight, food intake, and water intake; housing conditions had minimal impact on variation. In a multi-laboratory study where enrichment conditions and age were used to systematically introduce variation, differences between laboratories were the largest source of variation for nearly every behavioural measure [108]. In another large-scale study with two strains of mice, André et al. [109] found that nesting material and shelter did not increase variability in a broad range of physiological outcomes, concluding that experimental cohort was more influential than enrichment. Mieske et al. [110] housed mice in larger cages with several connected elevated levels and concluded that the variability of their resting metabolic rate was comparable to variability found in studies using conventional housing systems. Bailoo et al. [111] found no consistent relationship between enrichment and variation for any outcome (across a range of outcomes such as anxiety, endocrine responses, growth, and brain function), even with the use of larger and more complex environments. Indeed, deliberately introducing and embracing variability within a study might help to make results more replicable and generalisable [112,113].

\subsubsection{Risk of Altered Research Outcomes}

Several review articles focused on how enrichment might affect research outcomes $[46,50,53,54,70]$. However, it is important to note that results can be impacted by all environmental conditions, known or unknown; responses to status quo conditions should not be considered normal without evidence to support this assessment. Indeed, conventional housing is associated with a host of abnormal responses. For example, David et al. [26] found that mice housed in individually ventilated cages without shelters showed histologi- 
cal signs of chronic cold stress and altered experimental results (as measured by adrenal weights, tumour growth, and adipose tissue). Other aspects such as lighting, noise, smells, handling of animals, and other minor environmental changes can impact the animals involved in research [114].

Standardised conventional housing should not be considered to represent ideal experimental conditions given the low repeatability and translatability of preclinical animal research [115-118]. The idea that standardised housing contributes to reproducibility has been criticised (the standardisation fallacy; $[119,120])$. Crabbe et al. [121] assessed multiple strains of mice in three different laboratories using standardised husbandry and experimental protocols, and found effects of the laboratory in six of eight outcomes and interactions between laboratory and genotype for five outcomes. Thus, even standardised conditions can result in artefacts in the data or systematic overestimation of the effect of strain on experimental outcomes, when outcomes are in fact the result of an interaction between strain and laboratory-specific environmental conditions $[17,108]$. True standardisation of all environmental variables across laboratories is impossible, resulting in variation regardless of enrichment protocols; results may only be replicable if they are generalisable to a range of laboratory conditions [70,73,122,123].

Interpretations of experimental outcomes may differ depending on how housing conditions are framed. For example, we could reframe the shoebox cage as a treatment in which we are measuring the effects of persistent stressors related to an impoverished environment [124]. As described by Contreras and Rollin [33], (p. 21): “One must understand the normal behaviours, environment, and physiologic adaptations that the subject utilises to survive and thrive in the subject's environment. If one does not appreciate normal, one cannot recognise abnormal." Studies generally fail to acknowledge that the effects of enrichment are typically measured in comparison to animals that are predisposed to exhibit enhanced symptoms of disease [21] as a result of heightened stress in conventional cages [125] or single housing [68,126]. Enrichment is recognised as reducing symptoms for a wide range of rodent disease models, and is therefore recommended as a therapeutic treatment for human populations (e.g., [127,128]). However, even modest increases in enrichment can protect against disease in animal models; several articles have questioned the external validity and translatability of preclinical animal research using conventional housing, suggesting that "control" conditions in preclinical research should be "enriched" to improve research quality [46,129-131].

\subsubsection{Enrichment Programs Must Have Empirically Proven Benefits}

Most articles specified that enrichment must have benefits proven through empirical research, with some suggesting that professional judgments are insufficient [56]. Additional conditions were related to the quantity and type of evidence required to make changes; many articles called for the study of enrichment with the measurement of both physiological and behavioural outcomes. Such data has value, but these suggestions raise important questions, such as how much evidence is required to support changes in practice, and who should be responsible for generating this? Are those who propose welfare initiatives also expected to scientifically prove benefits [55], or should the burden fall upon researchers to show that existing housing methods are appropriate? Until these criteria are more transparently outlined by policymakers, open calls for "more research" are likely to delay implementation of refinements that have been studied [59].

Even when evidence is available, it may not be considered sufficiently compelling to motivate changes in practice. For example, some of the reviewed articles suggested that data on animal preferences should not be considered sufficient to draw conclusions regarding enrichment, arguing that animals can prefer options that are harmful (illustrated through examples of rodents provided access to unbalanced diets or addictive substances, e.g., [7]). The need for other types of evidence, such as measures of motivational strength or physiological outcomes, was emphasised by several authors [37,55,63,64]. While other measures are important to form a complete assessment of animal welfare, we suggest 
that preference results are useful so long as care is taken to consider the influence of current environmental conditions, previous experiences, the choices offered, and the testing methods used [82,132].

Researchers sometimes call for further evidence even in cases where evidence exists. For example, research has shown that typical laboratory rat cages do not provide sufficient vertical space [11,133], but lab animal stakeholders interviewed about cage height were generally unreceptive to change, citing a lack of scientific evidence [134]. In this example, stakeholders were seemingly influenced by their own experiences, assumptions about rat behaviour, or a desire to generate their own data. A similar phenomenon has been documented regarding the refinement of mouse handling methods; research on the effects of tail-handling has been conducted in several laboratories with different strains of mice $[135,136]$, but respondents in a recent survey expressed a desire for more evidence [101].

To aid progress, policy makers may wish to establish clear guidelines of the type and quantity of evidence required before adopting refinements, as well as who is expected to generate and evaluate this data. We encourage caging manufacturers to assess products for demonstrable animal welfare benefits before putting them on the market. It may also be useful to define what scientific criteria are necessary for researchers to opt out of providing recommended enrichment.

\subsubsection{Risks to Animal Health or Safety}

Although a major aim of enrichment is to improve the welfare of animals, the misapplication or misidentification of enrichment can have the opposite effect. Negative effects on animal health, behaviour, and wellbeing were identified as risks of enrichment in several articles. Some of these articles identified how poor choices of enrichment materials could increase injury or disease $[7,72,74]$. For example, paper tissues have been identified as inappropriate enrichment for mice used in asthma studies, because the cellulose fibres of these tissues contribute to inflammatory reactions of the lungs [137]. In another case, fibrous nesting material was noted as causing injury to mice [138]. Therefore, even for widely endorsed forms of enrichment such as nesting material, some options will be better than others and approaches may need to be altered depending on context. Several articles recommended certain enrichment strategies only conditionally, often citing the potential for increased aggression among male mice $[37,54,58,59,64,67]$.

Aggression among male laboratory mice is a complex issue. Aggression is a natural component of rodent behaviour and has rewarding properties [139], so providing mice with the freedom to express some of this behaviour (so long as subordinates can escape without harm) could be considered to provide welfare benefits. It is possible that previous studies have failed to provide sufficient quantities of enrichment to mitigate competition [140]. While there are many examples of structural enrichment resulting in increased aggression among males (e.g., [141,142]), there are also many cases of successful enrichment use (involving a range of genetic strains and enrichment strategies) [143-147]. In one example, male mice housed with hemp ropes hanging from the cage lid demonstrated more aggression when frequently tail-handled by experimenters; when handling was reduced, mice housed with hemp ropes showed no differences in aggression compared to the conventionally housed control group [145]. Therefore, reactions to enrichment could be context specific. We recommend further research into the welfare of male mice housed in more complex environments, specifically relating to causes and mitigation strategies for excessive aggression.

\subsubsection{Other Risks and Requirements}

The articles we reviewed also occasionally cited other risks or requirements of enrichment: potential for conflicts with standardised practices or ongoing experimental protocols (8 articles); staff must be motivated and knowledgeable about rodent behaviour (8 articles); issues related to existing facilities or cage dimensions ( 7 articles); resistance from personnel 
or researchers ( 5 articles); enrichment should not risk staff safety (4 articles); and enrichment should not impede visual inspection of animals ( 3 articles). One article specified that enrichment should be commercially available, while another suggested that enrichment must meet hygienic or biosafety requirements. Key [58] suggested that suitable enrichment must fulfil the "three Ps": Proven (enrichment should result in increase in species specific behaviours, decrease stereotypies, and no unacceptable increase in variability), Practical (enrichment should be easy to use), and Price (enrichment should be inexpensive). Notably, two of these three components are human-related, as were most of the themes in the risks or requirements category. These statements also often reflected the authors' own pragmatic concerns or the perceived concerns of other relevant stakeholders rather than representative data.

\subsection{Reviewing and Implementing Enrichment}

Some authors suggested how different factors should be weighed when considering the perceived risks described above. Baumans and Van Loo [69] suggested that animalrelated factors, scientific validity of the animal model, and factors related to the animal facility must be equally addressed in relation to enrichment; Conour et al. [67] suggested that animal welfare must be balanced with sound scientific practices; Sørenson et al. [61] and Bayne and Würbel [70] suggested that an enrichment cost-benefit analysis should be conducted in which welfare benefits are weighed against potential harms to research.

Some articles indicated who is responsible for assessing and implementing enrichment, but it is unclear how these recommendations line up with the perceived responsibilities of stakeholders. The primary investigator and husbandry staff were often cited as being responsible for enrichment, while some also listed the facility veterinarian and the animal ethics committee $[7,64,67,72]$. In reality, lab animal husbandry personnel often report having little to no control over provision of enrichment [99]. Additionally, 95\% of lab animal veterinarians surveyed in a recent study rated mouse welfare as acceptable to excellent in current conditions [148], so motivation to advocate for housing refinements may be low. In another study, most lab animal veterinarians and technicians agreed that institutional rules or regulations were sufficient to ensure quality of life for animals, and indicated that it was the responsibility of the animal ethics committee to address animal welfare concerns [149].

Although animal ethics committees play a role in reviewing and updating enrichment programs [150-152], it is unclear if ethics committees consider implementing refinements outside of experimental protocols as part of their role. A survey of non-human primate facilities in the United States found that only $36 \%$ of staff perceived strong support for enrichment from their institutional animal ethics committee [153]. Instead, these participants felt that inspections from regulators or accreditation programs prompted enhancements to enrichment programs much more often than did ethics committee reviews, suggesting that institutional animal ethics committees are not effective in promoting enrichment. Several factors may impede the promotion of enrichment by ethics committees, such as a general misunderstanding of what Refinement means, belief that animal welfare is already high, or a focus on mitigating pain caused by procedures rather than on quality of life related to animal husbandry [154]. Varied perceptions of individual responsibility for Refinement among lab animal stakeholders may represent a more implicit barrier to enrichment.

Decisions about what refinements to adopt will require some type of assessment and balancing of the benefits and risks. The discerning reader will have noted that there is extensive scientific research on the effects of environmental enrichment, but risks and requirements are sometimes stated without strong supporting evidence. We suggest that decision making processes place equal emphasis on the quality of evidence for both benefits and risks. Decision makers should also be aware of potential biases. For example, any cost-benefit analysis is likely to be subject to status quo bias (i.e., a preference to maintain the current state of affairs) as well as loss aversion (i.e., perceived risks or losses are viewed as more costly than bypassed gains; [155]). Thus, without appropriate safeguards in place, 
cost-benefit analyses of enrichment are likely to unduly favour the status quo, overestimate costs, and underestimate benefits. We call for decision making processes that explicitly articulate how risks and benefits were estimated and how decision makers attempted to avoid these biases.

\subsection{Future Directions}

There is considerable variation in the focus of contemporary animal welfare enrichment research. Research continues on the effects of more widely used housing additions such as shelters (e.g., [156,157]) and nesting material (e.g., [42,158]). Of note, studying the effects of a singular enrichment item is informative, but from a practical perspective this approach has been shown to be less effective at improving welfare than the provision of more extensive or diverse enrichment $[111,159,160]$. Alternative forms of enrichment such as positive reinforcement training [161] and burrowing (i.e., digging in a deep substrate to form burrows) [11,12] received less attention in the articles we reviewed; we encourage further research in these areas to better understand how to provide diverse behavioural opportunities that can benefit laboratory rodents.

While some aspects of laboratory housing could be altered immediately, it is likely not possible to provide ideal rodent environments within existing standard cages due to their restrictive dimensions [32,162]. Conditions that might allow for a "good life" in laboratory environments have been outlined by Makowska and Weary [32], but we may need considerably different housing conditions to achieve this [66]. Cage manufacturers have a key role to play in providing cages with dimensions that can accommodate more complex environmental components. In the more immediate future, creative enrichment solutions that overcome or work within current practical limitations are called for. Some examples of more immediately feasible enrichment include altered food provision to allow for more natural foraging [52], the provision of get-away tunnels or lofts to allow for more natural maternal care when dams are housed with pups [163,164], combining existing cages to allow for more space and structural components in a housing system $[165,166]$, repurposing of cages meant for larger species [167], repurposing of existing facility materials to make enrichment components [143], promoting positive human-animal interactions [168-170], and the use of temporary playpens in facilities that lack the space or resources to permanently house animals in more complex environments [3,43,171]. Notably, the environments of laboratory animals that are not used in experiments (e.g., breeding, training, or sentinel animals) could be improved with fewer constraints, given that they are not bound to experimental requirements [73]. Almost half of all animal research procedures in the UK in 2019 involved breeding for the creation or maintenance of genetically altered animals [172]; this represents a considerable opportunity for animals to benefit from increased environmental complexity.

\section{Conclusions}

Environmental enrichment is most often conceptualised as a method to increase natural behaviour and improve animal welfare. We advocate for the adoption of specific and value-neutral descriptors to explain exactly what elements of the environment are modified and how they are believed to affect the welfare of the animals. Such descriptions would help to clarify that not every cage alteration is beneficial for welfare, and to avoid framing basic features of housing systems as luxuries. Many review articles supported providing rodents with social housing, nesting material, provision of shelters or nest boxes, opportunities for foraging, and (for rats at least) larger environments. Given the near ubiquity of these recommendations, we suggest that these be framed as basic housing components for laboratory rodents; regardless, we suggest that researchers justify the framing they have employed when describing housing components, and understand the effect of this framing on their conclusions. The papers we reviewed often described perceived risks or requirements of enrichment, such as the need for more empirical evidence, practical and financial constraints, and the potential for enrichment to alter variability of 
research outcomes. The quality of evidence for these concerns was often not clear; we suggest that decision makers take this into consideration when attempting to conduct a cost-benefit analysis for the provision of environmental enrichment.

Author Contributions: Conceptualisation: A.S.R. and D.M.W.; methodology: A.S.R. and D.M.W.; writing-original draft preparation: A.S.R.; writing-review and editing: A.S.R. and D.M.W.; supervision: D.M.W. All authors have read and agreed to the published version of the manuscript.

Funding: A.S.R. was supported by an NSERC CGS Doctoral Award and the Charles River Scholarship in Animal Welfare. D.M.W.'s research is supported by a Discovery grant from the Natural Sciences and Engineering Research Council (RGPIN-2016-04620).

Data Availability Statement: Not applicable.

Acknowledgments: We thank Joanna Makowska and Lucía Améndola for helpful conversations and comments on earlier versions of this paper, and Afnan Ali for assisting as a second reviewer.

Conflicts of Interest: The authors declare no conflict of interest.

\section{References}

1. Gaskill, B.N.; Gouveia, K. The Mouse. In Animal-Centric Care and Management; Sørensen, D.B., Cloutier, S., Gaskill, B.N., Eds.; CRC Press: Boca Raton, FL, USA, 2021; Volume 1, pp. 103-119.

2. Latham, N.; Mason, G. From house mouse to mouse house: The behavioural biology of free-living Mus musculus and its implications in the laboratory. Appl. Anim. Behav. Sci. 2004, 86, 261-289. [CrossRef]

3. Makowska, I.J. The rat. In Animal-Centric Care and Management; Sørensen, D.B., Cloutier, S., Gaskill, B.N., Eds.; CRC Press: Boca Raton, FL, USA, 2021; Volume 1, pp. 121-134.

4. Barnett, S.A. The Rat: A Study in Behavior; The University of Chicago Press: Chicago, IL, USA, 1975.

5. Applebee, K. Rodent environmental enrichment-Animal welfare or human feel good factor. Anim. Welf. Technol. 2002, 1, 65-69.

6. Blanchard, R.J. Animal welfare beyond the cage ... and beyond the evidence? J. Appl. Anim. Welf. Sci. 2010, 13, 89-95. [CrossRef]

7. Toth, L.A.; Kregel, K.; Leon, L.; Musch, T.I. Environmental enrichment of laboratory rodents: The answer depends on the question. Comp. Med. 2011, 61, 314-321. [PubMed]

8. Price, E. Behavioral development in animals undergoing domestication. Appl. Anim. Behav. Sci. 1999, 65, 245-271. [CrossRef]

9. Boice, R. Burrows of wild and albino rats: Effects of domestication, outdoor raising, age, experience, and maternal state. J. Comp. Physiol. Psychol. 1977, 91, 649-661. [CrossRef] [PubMed]

10. Dudek, B.C.; Adams, N.; Boice, R.; Abbott, M.E. Genetic influences on digging behaviors in mice (Mus musculus) in laboratory and seminatural settings. J. Comp. Psychol. 1983, 97, 249-259. [CrossRef]

11. Makowska, I.J.; Weary, D.M. The importance of burrowing, climbing and standing upright for laboratory rats. R. Soc. Open Sci. 2016, 3, 160136. [CrossRef]

12. Sherwin, C.M.; Haug, E.; Terkelsen, N.; Vadgama, M. Studies on the motivation for burrowing by laboratory mice. Appl. Anim. Behav. Sci. 2004, 88, 343-358. [CrossRef]

13. Scharmann, W. Improved housing of mice, rats and guinea-pigs: A contribution to the refinement of animal experiments. Altern. Lab. Anim. 1991, 19, 108-114. [CrossRef]

14. National Research Council. Guide for the Care and Use of Laboratory Animals, 8th ed.; The National Academies Press: Washington, DC, USA, 2011.

15. Bracke, M.B.M.; Hopster, H. Assessing the importance of natural behavior for animal welfare. J. Agric. Environ. Ethics 2006, 19, 77-89. [CrossRef]

16. Lecorps, B.; Weary, D.M.; von Keyserlingk, M.A.G. Captivity-induced depression in animals. Trends Cogn. Sci. 2021, 25, 539-541. [CrossRef]

17. Garner, J.P. Stereotypies and other abnormal repetitive behaviors: Potential impact on validity, reliability, and replicability of scientific outcomes. ILAR J. 2005, 46, 106-117. [CrossRef]

18. Gross, A.N.; Richter, S.H.; Engel, A.K.J.; Würbel, H. Cage-induced stereotypies, perseveration and the effects of environmental enrichment in laboratory mice. Behav. Brain Res. 2012, 234, 61-68. [CrossRef]

19. Würbel, H. Stereotypies in laboratory mice-Quantitative and qualitative description. Ethology 1996, 102, 371-385. [CrossRef]

20. Brod, S.; Gobbetti, T.; Gittens, B.; Ono, M.; Perretti, M.; D’Acquisto, F. The impact of environmental enrichment on the murine inflammatory immune response. JCI Insight 2017, 2, e90723. [CrossRef]

21. Cait, J.; Cait, A.; Scott, R.W.; Winder, C.B.; Mason, G.J. Conventional laboratory housing increases morbidity and mortality in research rodents: Results of a meta-analysis. BMC Biol. 2021, 20, 15. [CrossRef]

22. Konkle, A.T.M.; Kentner, A.C.; Baker, S.L.; Stewart, A.; Bielajew, C. Environmental-enrichment-related variations in behavioral, biochemical, and physiologic responses of Sprague-Dawley and Long Evans rats. J. Am. Assoc. Lab. Anim. Sci. 2010, 49, 427-436.

23. Kulesskaya, N.; Rauvala, H.; Voikar, V. Evaluation of social and physical enrichment in modulation of behavioural phenotype in C57BL/6J female mice. PLoS ONE 2011, 6, e24755. [CrossRef] 
24. Sherwin, C.M.; Olsson, I.A.S. Housing conditions affect self-administration of anxiolytic by laboratory mice. Anim. Welf. 2004, 13, 33-38.

25. Kimura, L.F.; de Moura Mattaraia, V.G.; Picolo, G. Distinct environmental enrichment protocols reduce anxiety but differentially modulate pain sensitivity in rats. Behav. Brain Res. 2019, 364, 442-446. [CrossRef]

26. David, J.M.; Knowles, S.; Lamkin, D.M.; Stout, D.B. Individually ventilated cages impose cold stress on laboratory mice: A source of systemic experimental variability. J. Am. Assoc. Lab. Anim. Sci. 2013, 52, 738-744.

27. Canadian Council on Animal Care. Guide to the Care and Use of Experimental Animals; CCAC: Ottawa, CA, USA, $1984 ;$ Volume 2.

28. Canadian Council on Animal Care. CCAC Guidelines: Mice. 2019. Available online: https://ccac.ca/Documents/Standards/Gu idelines/CCAC_Guidelines_Mice.pdf (accessed on 3 January 2021).

29. Canadian Council on Animal Care. CCAC Guidelines: Rats. 2020. Available online: https://ccac.ca/Documents/Standards/Gu idelines/CCAC_Guidelines_Rats.pdf (accessed on 3 January 2021).

30. DeGrazia, D.; Beauchamp, T.L. Beyond the 3 Rs to a more comprehensive framework of principles for animal research ethics. ILAR J. 2019, 60, 308-317. [CrossRef]

31. MacArthur Clark, J. The 3Rs in research: A contemporary approach to replacement, reduction and refinement. Br. J. Nutr. 2018, 120, S1-S7. [CrossRef]

32. Makowska, I.J.; Weary, D.M. A good life for laboratory rodents? ILAR J. 2020, 60, 373-388. [CrossRef]

33. Contreras, E.T.; Rollin, B.E. The convenient disregard for the Rattus species in the laboratory environment: Implications for animal welfare and science. J. Anim. Ethics 2021, 11, 12-30. [CrossRef]

34. Poole, T. Happy animals make good science. Lab. Anim. 1997, 31, 116-124. [CrossRef]

35. Sherwin, C.M. The influences of standard laboratory cages on rodents and the validity of research data. Anim. Welf. 2004, 13, 9-15.

36. Newberry, R.C. Environmental enrichment: Increasing the biological relevance of captive environments. Appl. Anim. Behav. Sci. 1995, 44, 229-243. [CrossRef]

37. Olsson, I.A.S.; Dahlborn, K. Improving housing conditions for laboratory mice: A review of "environmental enrichment". Lab. Anim. 2002, 36, 243-270. [CrossRef]

38. Vitalo, A.; Fricchione, J.; Casali, M.; Berdichevsky, Y.; Hoge, E.A.; Rauch, S.L.; Berthiaume, F.; Yarmush, M.L.; Benson, H.; Fricchione, G.L.; et al. Nest making and oxytocin comparably promote wound healing in isolation reared rats. PLoS ONE 2009, 4, e5523. [CrossRef] [PubMed]

39. Churchill, S.R.; Morgan, D.L.; Kissling, G.E.; Travlos, G.S.; King-Herbert, A.P. Impact of environmental enrichment devices on NTP in vivo studies. Toxicol. Pathol. 2016, 44, 233-245. [CrossRef] [PubMed]

40. Acklin, C.J.; Gault, R.A. Effects of natural enrichment materials on stress, memory and exploratory behavior in mice. Lab. Anim. 2015, 44, 262-267. [CrossRef] [PubMed]

41. Latham, N.; Mason, G. Frustration and perseveration in stereotypic captive animals: Is a taste of enrichment worse than none at all? Behav. Brain Res. 2010, 211, 96-104. [CrossRef] [PubMed]

42. Khoo, S.Y.S.; Correia, V.; Uhrig, A. Nesting material enrichment reduces severity of overgrooming-related self-injury in individually housed rats. Lab. Anim. 2020, 54, 546-558. [CrossRef] [PubMed]

43. Ratuski, A.S.; Makowska, I.J.; Dvorack, K.R.; Weary, D.M. Using approach latency and anticipatory behaviour to assess whether voluntary playpen access is rewarding to laboratory mice. Sci. Rep. 2021, 11, 18683. [CrossRef]

44. Tecniplast Emerald IVC. Available online: https://www.tecniplast.it/en/emerald-ivc.html (accessed on 30 December 2021).

45. De Azevedo, C.S.; Cipreste, C.F.; Young, R.J. Environmental enrichment: A GAP analysis. Appl. Anim. Behav. Sci. 2007, 102, 329-343. [CrossRef]

46. Kentner, A.C.; Speno, A.V.; Doucette, J.; Roderick, R.C. The contribution of environmental enrichment to phenotypic variation in mice and rats. eNeuro 2021, 8, ENEURO.0539-20.2021. [CrossRef]

47. Kilkenny, C.; Browne, W.J.; Cuthill, I.C.; Emerson, M.; Altman, D.G. Improving bioscience research reporting: The ARRIVE guidelines for reporting animal research. PLoS Biol. 2010, 8, 6-10. [CrossRef]

48. Percie du Sert, N.; Hurst, V.; Ahluwalia, A.; Alam, S.; Avey, M.T.; Baker, M.; Browne, W.J.; Clark, A.; Cuthill, I.C.; Dirnagl, U.; et al. The ARRIVE guidelines 2.0: Updated guidelines for reporting animal research. J. Cereb. Blood Flow Metab. 2020, 40, $1769-1777$. [CrossRef]

49. Munn, Z.; Peters, M.; Stern, C.; Tufanaru, C.; McArthur, A.; Aromataris, E. Systematic review or scoping review? Guidance for authors when choosing between a systematic or scoping review approach. BMC Med. Res. Methodol. 2018, 18, 143. [CrossRef]

50. Bayne, K. Potential for unintended consequences of environmental enrichment for laboratory animals and research results. ILAR J. 2005, 46, 129-139. [CrossRef]

51. Brown, C. Novel food items as environmental enrichment for rodents and rabbits. Lab Anim. (NY) 2009, 38, 119-120. [CrossRef]

52. Johnson, S.R.; Patterson-Kane, E.G. Foraging as environmental enrichment for laboratory rats: A theoretical review. Anim. Welf. Technol. 2003, 2, 13-22.

53. Van de Weerd, H.A.; Van Loo, P.L.P.; Baumans, V. Environmental enrichment: Room for reduction? Altern. Lab. Anim. 2004, 32, 69-71. [CrossRef]

54. Würbel, H.; Garner, J.P. Refinement of rodent research through environmental enrichment and systematic randomization. Natl. Cent. Replace. Refinement Reduct. Anim. Res. 2007, 9, 1-9. [CrossRef] 
55. Dean, S.W. Environmental enrichment of laboratory animals used in regulatory toxicology studies. Lab. Anim. 1999, 33, 309-327. [CrossRef]

56. Galef, B.G., Jr. Environmental enrichment for laboratory rodents: Animal welfare and the methods of science. J. Appl. Anim. Welf. Sci. 1999, 2, 267-280. [CrossRef]

57. Hawkins, P.; Jennings, M. Rodent enrichment dilemmas-The answers are out there! Anim. Welf. Technol. 2004, 3, $143-147$.

58. Key, D. Environmental enrichment options for laboratory rats and mice. Lab Anim. 2004, 33, 39-44. [CrossRef]

59. Ottesen, J.L.; Weber, A.; Gürtler, H.; Mikkelsen, L.F. New housing conditions: Improving the welfare of experimental animals. Altern. Lab. Anim. 2004, 32, 397-404. [CrossRef]

60. Patterson-Kane, E.G. Enrichment of laboratory caging for rats: A review. Anim. Welf. 2004, 13, $209-214$.

61. Sørensen, D.B.; Ottesen, J.L.; Hansen, A.K. Consequences of enhancing environmental complexity for laboratory rodents-A review with emphasis on the rat. Anim. Welf. 2004, 13, 193-204.

62. Baumans, V. Environmental enrichment for laboratory rodents and rabbits: Requirements of rodents, rabbits, and research. ILAR J. 2005, 46, 162-170. [CrossRef]

63. Benefiel, A.C.; Dong, W.K.; Greenough, W.T. Mandatory "enriched" housing of laboratory animals: The need for evidence-based evaluation. ILAR J. 2005, 46, 95-105. [CrossRef]

64. Hutchinson, E.; Avery, A.; VandeWoude, S. Environmental enrichment for laboratory rodents. ILAR J. 2005, 46, 148-161. [CrossRef]

65. Smith, A.L.; Corrow, D.J. Modifications to husbandry and housing conditions of laboratory rodents for improved well-being. ILAR J. 2005, 46, 140-147. [CrossRef]

66. Balcombe, J.P. Laboratory environments and rodents' behavioural needs: A review. Lab. Anim. 2006, 40, 217-235. [CrossRef]

67. Conour, L.A.; Murray, K.A.; Brown, M.J. Preparation of animals for research-Issues to consider for rodents and rabbits. ILAR J. 2006, 47, 283-293. [CrossRef]

68. Simpson, J.; Kelly, J.P. The impact of environmental enrichment in laboratory rats-Behavioural and neurochemical aspects. Behav. Brain Res. 2011, 222, 246-264. [CrossRef]

69. Baumans, V.; Van Loo, P.L.P. How to improve housing conditions of laboratory animals: The possibilities of environmental refinement. Vet. J. 2013, 195, 24-32. [CrossRef] [PubMed]

70. Bayne, K.; Würbel, H. The impact of environmental enrichment on the outcome variability and scientific validity of laboratory animal studies. OIE Rev. Sci. Tech. 2014, 33, 273-280. [CrossRef] [PubMed]

71. Jirkof, P. Effects of experimental housing conditions on recovery of laboratory mice. Lab Anim. 2015, 44, 65-70. [CrossRef] [PubMed]

72. Bayne, K. Environmental enrichment and mouse models: Current perspectives. Anim. Model. Exp. Med. 2018, 1, 82-90. [CrossRef]

73. Lewejohann, L.; Schwabe, K.; Häger, C.; Jirkof, P. Impulse for animal welfare outside the experiment. Lab. Anim. 2020, 54, 150-158. [CrossRef]

74. Pritchett-Corning, K.R. Environmental complexity and research outcomes. ILAR J. 2020, 60, 239-251. [CrossRef]

75. Fraser, D.; Weary, D.M.; Pajor, E.A.; Milligan, B.N. A scientific conception of animal welfare that reflects ethical concerns. Anim. Welf. 1997, 6, 187-205.

76. Broom, D.M. Animal welfare: Concepts and measurement. J. Anim. Sci. 1991, 69, 4167-4175. [CrossRef]

77. Barnard, C.J.; Hurst, J.L. Welfare by design: The natural selection of welfare criteria. Anim. Welf. 1996, 5, 405-433.

78. Dawkins, M.S. The science of animal suffering. Ethology 2008, 114, 937-945. [CrossRef]

79. Franks, B.; Tory Higgins, E. Effectiveness in Humans and Other Animals. A Common Basis for Well-being and Welfare. In Advances in Experimental Social Psychology, 1st ed.; Academic Press: Cambridge, MA, USA, 2012; Volume 46, pp. 285-346. [CrossRef]

80. Špinka, M. Animal agency, animal awareness and animal welfare. Anim. Welf. 2019, 28, 11-20. [CrossRef]

81. Weary, D.M.; Robbins, J.A. Understanding the multiple conceptions of animal welfare. Anim. Welf. 2019, 28, 33-40. [CrossRef]

82. Mench, J. Why it is important to understand animal behavior. ILAR J. 1998, 39, 20-26. [CrossRef]

83. Fraser, D. Understanding Animal Welfare: The Science in its Cultural Context; Wiley-Blackwell: Oxford, UK, 2008.

84. Crawford, L.E.; Knouse, L.E.; Kent, M.; Vavra, D.; Harding, O.; LeServe, D.; Fox, N.; Hu, X.; Li, P.; Glory, C.; et al. Enriched environment exposure accelerates rodent driving skills. Behav. Brain Res. 2020, 378, 112309. [CrossRef]

85. Miller, L.J.; Vicino, G.A.; Sheftel, J.; Lauderdale, L.K. Behavioral diversity as a potential indicator of positive animal welfare. Animals 2020, 10, 1211. [CrossRef]

86. Mason, G. Stereotypies and suffering. Behav. Processes 1991, 25, 103-115. [CrossRef]

87. Mason, G.; Latham, N. Can't stop, won't stop: Is stereotypy a reliable wefare indicator? Anim. Welf. 2004, 13, 57-69.

88. Patterson-Kane, E.G.; Harper, D.N.; Hunt, M. The cage preferences of laboratory rats. Lab. Anim. 2001, 35, 74-79. [CrossRef]

89. Arranz, L.; De Castro, N.M.; Baeza, I.; Mate, I.; Paz Viveros, M.; De la Fuente, M. Environmental enrichment improves age-related immune system impairment: Long-term exposure since adulthood increases life span in mice. Rejuvenation Res. 2010, 13, 415-428. [CrossRef]

90. Rodríguez-Ortega, E.; Alcaraz-Iborra, M.; de la Fuente, L.; Cubero, I. Protective and therapeutic benefits of environmental enrichment on binge-like sucrose intake in C57BL/6J mice. Appetite 2019, 138, 184-189. [CrossRef]

91. Nevison, C.M.; Hurst, J.L.; Barnard, C.J. Strain-Specific effects of cage enrichment in male laboratory mice (Mus musculus). Anim. Welf. 1999, 8, 361-379. 
92. King, J. Report of the enrichment; awareness and uptake workshop 2018 on 26th June at College Court, Leicester. Anim. Technol. Welf. 2018, 17, 163-167.

93. Canadian Council on Animal Care. CCAC Guidelines: Husbandry of Animals Used in Science. 2017. Available online: https:/ / ccac.ca/Documents/Standards/Guidelines/CCAC-guidelines-on-husbandry-of-animals-in-science.pdf (accessed on 3 January 2021).

94. Fenwick, N.; Danielson, P.; Griffin, G. Survey of Canadian animal-based researchers' views on the Three Rs: Replacement, reduction and refinement. PLoS ONE 2011, 6, e22478. [CrossRef]

95. Anneberg, I.; Lassen, J.; Sandøe, P. For the sake of production-And the animal, and me. How students at danish agricultural colleges perceive animal welfare. Animals 2021, 11, 696. [CrossRef]

96. Dawkins, M.S. Animal welfare and efficient farming: Is conflict inevitable? Anim. Prod. Sci. 2017, 57, 201-208. [CrossRef]

97. Stevens, C.H.; Reed, B.T.; Hawkins, P. Enrichment for laboratory zebrafish-A review of the evidence and the challenges. Animals 2021, 11, 698. [CrossRef]

98. LaFollette, M.R.; Cloutier, S.; Brady, C.; Gaskill, B.N.; O'Haire, M.E. Laboratory animal welfare and human attitudes: A cross-sectional survey on heterospecific play or "rat tickling". PLoS ONE 2019, 14, e0220580. [CrossRef]

99. LaFollette, M.R.; Riley, M.C.; Cloutier, S.; Brady, C.M.; O’Haire, M.E.; Gaskill, B.N. Laboratory animal welfare meets human welfare: A cross-sectional study of professional quality of life, including compassion fatigue in laboratory animal personnel. Front. Vet. Sci. 2020, 7, 114. [CrossRef] [PubMed]

100. Baumans, V.; Van Loo, P.L.P.; Pham, T.M. Standardisation of environmental enrichment for laboratory mice and rats: Utilisation, practicality and variation in experimental results. Scand. J. Lab. Anim. Sci. 2010, 37, 101-114.

101. Henderson, L.J.; Smulders, T.V.; Roughan, J.V. Identifying obstacles preventing the uptake of tunnel handling methods for laboratory mice: An international thematic survey. PLoS ONE 2020, 15, e0231454. [CrossRef] [PubMed]

102. Brunt, M.W.; Améndola, L.; Weary, D.M. Attitudes of laboratory animal professionals and researchers towards carbon dioxide euthanasia for rodents and perceived barriers to change. Lab. Anim. 2021, 55, 531-539. [CrossRef]

103. Hoy, J.M.; Murray, P.J.; Tribe, A. Thirty years later: Enrichment practices for captive mammals. Zoo Biol. 2010, $29,303-316$. [CrossRef]

104. Riley, L.M.; Rose, P.E. Concepts, applications, uses and evaluation of environmental enrichment. J. Zoo Aquar. Res. 2020, 8, 18-28.

105. Kovach, J.V.; Dash, A. Using the lean six sigma methodology to reduce mouse cage sanitation time for animal care and use programs. J. Am. Assoc. Lab. Anim. Sci. 2019, 58, 551-557. [CrossRef]

106. Chang, F.T.; Hart, L.A. Human-animal bonds in the laboratory: How animal behavior affects the perspective of caregivers. ILAR J. 2002, 43, 10-18. [CrossRef]

107. Augustsson, H.; Van De Weerd, H.A.; Kruitwagen, C.L.J.J.; Baumans, V. Effect of enrichment on variation and results in the light/dark test. Lab. Anim. 2003, 37, 328-340. [CrossRef]

108. Richter, S.H.; Garner, J.P.; Zipser, B.; Lewejohann, L.; Sachser, N.; Touma, C.; Schindler, B.; Chourbaji, S.; Brandwein, C.; Gass, P.; et al. Effect of population heterogenization on the reproducibility of mouse behavior: A multi-laboratory study. PLoS ONE 2011, 6, e16461. [CrossRef]

109. André, V.; Gau, C.; Scheideler, A.; Aguilar-Pimentel, J.A.; Amarie, O.V.; Becker, L.; Garrett, L.; Hans, W.; Hölter, S.M.; Janik, D.; et al. Laboratory mouse housing conditions can be improved using common environmental enrichment without compromising data. PLoS Biol. 2018, 16, e2005019. [CrossRef]

110. Mieske, P.; Diederich, K.; Lewejohann, L. Roaming in a land of milk and honey: Life trajectories and metabolic rate of female inbred mice living in a semi naturalistic environment. Animals 2021, 11, 3002. [CrossRef]

111. Bailoo, J.D.; Murphy, E.; Boada-Saña, M.; Varholick, J.A.; Hintze, S.; Baussière, C.; Hahn, K.C.; Göpfert, C.; Palme, R.; Voelkl, B.; et al. Effects of cage enrichment on behavior, welfare and outcome variability in female mice. Front. Behav. Neurosci. 2018, 12, 232. [CrossRef]

112. Richter, S.H. Systematic heterogenization for better reproducibility in animal experimentation. Lab Anim. (NY) 2017, 46, 343-349. [CrossRef]

113. Usui, T.; Macleod, M.R.; Mccann, S.K.; Senior, A.M.; Nakagawa, S. Meta-analysis of variation suggests that embracing variability improves both replicability and generalizability in preclinical research. PLoS Biol. 2021, 19, e3001009. [CrossRef]

114. Toth, L.A. The influence of the cage environment on rodent physiology and behavior: Implications for reproducibility of pre-clinical rodent research. Exp. Neurol. 2015, 270, 72-77. [CrossRef]

115. Landi, M.; Everitt, J.; Berridge, B. Bioethical, reproducibility, and translational challenges of animal models. ILAR J. 2021 , ilaa027. [CrossRef]

116. Pound, P.; Bracken, M.B. Is animal research sufficiently evidence based to be a cornerstone of biomedical research? BMJ 2014, 348, g3387. [CrossRef]

117. Smith, B.L.; Lyons, C.E.; Correa, F.G.; Benoit, S.C.; Myers, B.; Solomon, M.B.; Herman, J.P. Behavioral and physiological consequences of enrichment loss in rats. Psychoneuroendocrinology 2017, 77, 37-46. [CrossRef]

118. Van der Worp, H.B.; Howells, D.W.; Sena, E.S.; Porritt, M.J.; Rewell, S.; O'Collins, V.; Macleod, M.R. Can animal models of disease reliably inform human studies? PLoS Med. 2010, 7, e1000245. [CrossRef]

119. Würbel, H. Behaviour and the standardization fallacy. Nat. Genet. 2000, 26, 263. [CrossRef]

120. Voelkl, B.; Würbel, H.; Krzywinski, M.; Altman, N. The standardization fallacy. Nat. Methods 2021, 18, 3-7. [CrossRef] 
121. Crabbe, J.C.; Wahlsten, D.; Dudek, B.C. Genetics of mouse behavior: Interactions with laboratory environment. Science 1999, 284, 1670-1672. [CrossRef]

122. Kafkafi, N.; Agassi, J.; Chesler, E.J.; Crabbe, J.C.; Crusio, W.E.; Eilam, D.; Gerlai, R.; Golani, I.; Gomez-Marin, A.; Heller, R.; et al. Reproducibility and replicability of rodent phenotyping in preclinical studies. Neurosci. Biobehav. Rev. 2018, 87, $218-232$. [CrossRef] [PubMed]

123. Voelkl, B.; Altman, N.S.; Forsman, A.; Forstmeier, W.; Gurevitch, J.; Jaric, I.; Karp, N.A.; Kas, M.J.; Schielzeth, H.; Van de Casteele, T.; et al. Reproducibility of animal research in light of biological variation. Nat. Rev. Neurosci. 2020, 21, 384-393. [CrossRef] [PubMed]

124. Bailey, J. Does the stress of laboratory life and experimentation on animals adversely affect research data? A critical review. Altern. Lab. Anim. 2018, 46, 291-305. [CrossRef] [PubMed]

125. Martin, B.; Ji, S.; Maudsley, S.; Mattson, M.P. “Control” laboratory rodents are metabolically morbid: Why it matters. Proc. Natl. Acad. Sci. USA 2010, 107, 6127-6133. [CrossRef] [PubMed]

126. Baker, S.; Bielajew, C. Influence of housing on the consequences of chronic mild stress in female rats. Stress 2007, 10, 283-293. [CrossRef]

127. Hannan, A.J. Review: Environmental enrichment and brain repair: Harnessing the therapeutic effects of cognitive stimulation and physical activity to enhance experience-dependent plasticity. Neuropathol. Appl. Neurobiol. 2014, 40, 13-25. [CrossRef]

128. Solinas, M.; Thiriet, N.; Chauvet, C.; Jaber, M. Prevention and treatment of drug addiction by environmental enrichment. Prog. Neurobiol. 2010, 92, 572-592. [CrossRef]

129. Laviola, G.; Hannan, A.J.; Macrì, S.; Solinas, M.; Jaber, M. Effects of enriched environment on animal models of neurodegenerative diseases and psychiatric disorders. Neurobiol. Dis. 2008, 31, 159-168. [CrossRef]

130. Nithianantharajah, J.; Hannan, A.J. Enriched environments, experience-dependent plasticity and disorders of the nervous system. Nat. Rev. Neurosci. 2006, 7, 697-709. [CrossRef]

131. Rojas-Carvajal, M.; Sequeira-Cordero, A.; Brenes, J.C. The environmental enrichment model revisited: A translatable paradigm to study the stress of our modern lifestyle. Eur. J. Neurosci. 2021, 1-34. [CrossRef]

132. Fraser, D.; Matthews, L.R. Preference and motivation testing. In Animal Welfare; Appleby, M.C., Hughes, B.O., Eds.; CAB International: New York, NY, USA, 1997; pp. 159-173.

133. Wheeler, R.R.; Swan, M.P.; Hickman, D.L. Effect of multilevel laboratory rat caging system on the well-being of the singly-housed sprague dawley rat. Lab. Anim. 2015, 49, 10-19. [CrossRef]

134. Mazhary, H.; Hawkins, P. Applying the 3Rs: A case study on evidence and perceptions relating to rat cage height in the UK. Animals 2019, 9, 1104. [CrossRef]

135. Hurst, J.L.; West, R.S. Taming anxiety in laboratory mice. Nat. Methods 2010, 7, 825-826. [CrossRef]

136. Clarkson, J.M.; Dwyer, D.M.; Flecknell, P.A.; Leach, M.C.; Rowe, C. Handling method alters the hedonic value of reward in laboratory mice. Sci. Rep. 2018, 8, 2448. [CrossRef]

137. Pasalic, I.; Bosnjak, B.; Tkalcevic, V.I.; Jaran, D.S.; Javorscak, Z.; Markovic, D.; Hrvacic, B. Cage enrichment with paper tissue, but not plastic tunnels, increases variability in mouse model of asthma. Lab. Anim. 2011, 45, 121-123. [CrossRef]

138. Northrup, E.; Held, N.; Hedrich, H.J.; Bleich, A. Mice may become caught in nesting material. Lab Anim. 2012, 41, 147. [CrossRef]

139. Borland, J.M.; Kim, E.; Swanson, S.P.; Rothwell, P.E.; Mermelstein, P.G.; Meisel, R.L. Effect of aggressive experience in female syrian hamsters on glutamate receptor expression in the nucleus accumbens. Front. Behav. Neurosci. 2020, 14, 583395. [CrossRef]

140. Weber, E.M.; Dallaire, J.A.; Gaskill, B.N.; Pritchett-Corning, K.R.; Garner, J.P. Aggression in group-housed laboratory mice: Why can't we solve the problem? Lab Anim. 2017, 46, 157-161. [CrossRef]

141. Howerton, C.L.; Garner, J.P.; Mench, J.A. Effects of a running wheel-igloo enrichment on aggression, hierarchy linearity, and stereotypy in group-housed male CD-1 (ICR) mice. Appl. Anim. Behav. Sci. 2008, 115, 90-103. [CrossRef]

142. Marashi, V.; Barnekow, A.; Ossendorf, E.; Sachser, N. Effects of different forms of environmental enrichment on behavioral, endocrinological, and immunological parameters in male mice. Horm. Behav. 2003, 43, 281-292. [CrossRef]

143. Vogt, M.A.; Mertens, S.; Serba, S.; Palme, R.; Chourbaji, S. The 'Cage Climber'-A new enrichment for use in large-dimensioned mouse facilities. Appl. Anim. Behav. Sci. 2020, 230, 105078. [CrossRef]

144. Lima, F.B.; Spinelli de Oliveira, E. What is the impact of low testosterone levels on the anatomical and behavioral repertoire of long-term enriched housing of male mice? Behav. Processes 2014, 108, 57-64. [CrossRef]

145. Gjendal, K.; Sørensen, D.B.; Kiersgaard, M.K.; Ottesen, J.L. Hang on: An evaluation of the hemp rope as environmental enrichment in C57BL/ 6 mice. Anim. Welf. 2017, 26, 437-447. [CrossRef]

146. Marashi, V.; Barnekow, A.; Sachser, N. Effects of environmental enrichment on males of a docile inbred strain of mice. Physiol. Behav. 2004, 82, 765-776. [CrossRef]

147. Slater, A.M.; Cao, L. A protocol for housing mice in an enriched environment. J. Vis. Exp. 2015, 100, e52874. [CrossRef]

148. Marx, J.O.; Jacobsen, K.O.; Petervary, N.A.; Casebolt, D.B. A survey of laboratory animal veterinarians regarding mouse welfare in biomedical research. J. Am. Assoc. Lab. Anim. Sci. 2021, 60, 139-145. [CrossRef]

149. Engel, R.M.; Silver, C.C.; Veeder, C.L.; Banks, R.E. Cognitive dissonance in laboratory animal medicine and implications for animal welfare. J. Am. Assoc. Lab. Anim. Sci. 2020, 59, 132-138. [CrossRef]

150. Directive 2010/63/EU of the European parliament and of the Council of 22 September 2010 on the protection of animals used for scientific purposes. Off. J. Eur. Union 2010, 276, 33-79. 
151. MacArthur Clark, J.A.; Sun, D. Guidelines for the ethical review of laboratory animal welfare People's Republic of China National Standard GB/T 35892-2018. Anim. Model. Exp. Med. 2020, 3, 103-113. [CrossRef] [PubMed]

152. Home Office. Code of Practice for the Housing and Care of Animals Bred, Supplied or Used for Scientific Purposes; UK Home Office: London, UK, 2014; Volume 21, pp. 1-212.

153. Baker, K. Enrichment and primate centers: Closing the gap between research and practice. J. Appl. Anim. Welf. Sci. 2007, 10, 49-54. [CrossRef] [PubMed]

154. Schuppli, C.A.; Fraser, D. The interpretation and application of the Three Rs by animal ethics committee members. Altern. Lab. Anim. 2005, 33, 487-500. [CrossRef]

155. Kahneman, D.; Knetsch, J.L.; Thaler, R.H. Anomalies: The endowment effect, loss aversion, and status quo bias. Choices Values Fram. 2019, 5, 159-170. [CrossRef]

156. Oatess, T.; Harrison, F.E.; Himmel, L.E.; Jones, C.P. Effects of Acrylic Tunnel Enrichment on Anxiety-Like Behavior, Neurogenesis, and Physiology of C57BL/6J Mice. J. Am. Assoc. Lab. Anim. Sci. 2021, 60, 44-53. [CrossRef]

157. Peveler, J.L.; Swan, M.P.; Wheeler, R.R.; Boehm, C.A.; Hickman, D.L. Effects of various commercially available enrichment options on handling and chronic stress markers in female ICR mice. J. Am. Assoc. Lab. Anim. Sci. 2019, 58, 119-125. [CrossRef]

158. Moreira, V.B.; Mattaraia, V.G.M.; Rodrigues, M.V.; de Albuquerque, C.Z.; Moura, A.S.A.M.T. Parental behavior and anxiety in isogenic and outbred mice given access to two types of nesting materials. Appl. Anim. Behav. Sci. 2019, 215, 68-76. [CrossRef]

159. Abou-Ismail, U.A. Are the effects of enrichment due to the presence of multiple items or a particular item in the cages of laboratory rat? Appl. Anim. Behav. Sci. 2011, 134, 72-82. [CrossRef]

160. Abou-Ismail, U.A.; Mendl, M.T. The effects of enrichment novelty versus complexity in cages of group-housed rats (Rattus norvegicus). Appl. Anim. Behav. Sci. 2016, 180, 130-139. [CrossRef]

161. Leidinger, C.; Herrmann, F.; Thöne-Reineke, C.; Baumgart, N.; Baumgart, J. Introducing clicker training as a cognitive enrichment for laboratory mice. J. Vis. Exp. 2017, 2017, e55415. [CrossRef]

162. Balcombe, J.P. Laboratory rodent welfare: Thinking outside the cage. J. Appl. Anim. Welf. Sci. 2010, 13, 77-88. [CrossRef]

163. Ratuski, A.S.; Weary, D.M. A break from the pups: The effects of loft access on the welfare of lactating laboratory rats. PLoS ONE 2021, 16, e0253020. [CrossRef]

164. Weaver, S.R.; Cronick, C.M.; Prichard, A.P.; Laporta, J.; Benevenga, N.J.; Hernandez, L.L. Use of the RatLoft decreases pup mortality in lactating mice. Lab. Anim. 2016, 50, 370-378. [CrossRef]

165. Améndola, L.; Ratuski, A.; Weary, D.M. Individual differences in rat sensitivity to CO2. PLoS ONE 2021, 16, e0245347. [CrossRef]

166. Makowska, I.J.; Franks, B.; El-Hinn, C.; Jorgensen, T.; Weary, D.M. Standard laboratory housing for mice restricts their ability to segregate space into clean and dirty areas. Sci. Rep. 2019, 9, 6179. [CrossRef]

167. Lidfors, L.; Wichman, A.; Ewaldsson, B.; Lindh, A.S. Enriched cages for groups of laboratory male rats and their effects on behaviour, weight gain and adrenal glands. Lab. Anim. 2014, 48, 36-49. [CrossRef]

168. Westlund, K. Training is enrichment-And beyond. Appl. Anim. Behav. Sci. 2014, 152, 1-6. [CrossRef]

169. Clark, F.E. Cognitive enrichment and welfare: Current approaches and future directions. Anim. Behav. Cogn. 2017, 4, 52-71. [CrossRef]

170. LaFollette, M.R.; O’Haire, M.E.; Cloutier, S.; Blankenberger, W.B.; Gaskill, B.N. Rat tickling: A systematic review of applications, outcomes, and moderators. PLoS ONE 2017, 12, e0175320. [CrossRef]

171. NC3Rs IAT Congress 2017 Workshop summary: Playtime for Rats. Available online: https://www.nc3rs.org.uk/iat-congress-20 17-workshop-summary-playtime-rats (accessed on 3 January 2021).

172. Home Office. Annual Statistics of Scientific Procedures on Living Animals, Great Britain 2019. 2020. Available online: https://assets.publishing.service.gov.uk/government/uploads/system/uploads/attachment_data/file/901224/annual-statis tics-scientific-procedures-living-animals-2019.pdf (accessed on 3 January 2021). 